\title{
THE OLDE ORDER CRUMBLETH: HIV- PESTILENCE AS A SECURITY ISSUE \& NEW THINKING ABOUT CORE CONCEPTS IN INTERNATIONAL AFFAIRS
}

\author{
J.M. Spectar*
}

\section{INTRODUCTION}

There is growing realization that in certain regions of the world the unusual virulence of AIDS is connected to the prevalence of insecurity and destabilizing conflict in a mutually reinforcing relationship. The recognition of AIDS as a security issue has significant implications for international law, politics, and diplomacy, particularly on the traditional conceptions of national interest, sovereignty, and non-intervention. This article examines the implications of the link between AIDS and security, focusing particularly on certain policy responses of key international actors, including the UN Security Council and the Clinton Administration. The article argues that the (belated) but nonetheless robust global response, particularly the Security Council resolution on AIDS, signified the on-going development of a new consensus about international governance in an age of galloping globalization and globetrotting super-viruses. ${ }^{1}$

In Part II, the article focuses on the emerging consensus that AIDS is a security threat, in terms of human security ${ }^{2}$ as well as national and international security. With respect to human security, the article describes how AIDS weakens and destroys families, communities, economies and

* Ph.D.1999, Claremont Graduate University; M.A.P. 1997, Claremont Graduate School; J.D. 1992, University of Maryland School of Law; M.A. 1992, George Washington University; M.B.A. 1989, Frostburg State University. Associate Provost for Academic Affairs \& Professor of Political Science, University of Scranton, PA. This article is an outgrowth of my notes for a seminar I taught in Princeton University during the spring of 2002 as well as my preparation for a human rights symposium at the University of Connecticut School of Law in December 2001. In addition, the article is also an extension of a lecture this author delivered in Princeton University titled, "Non-State Violence, HIV-Pestilence \& Other Emerging Threats: Rethinking National Interest, Sovereignty and Non-Intervention." (Sept. 2002). I would like to express my gratitude to all who participated in these events for their beneficial comments and thought provoking questions. I would also like to thank my former Princeton University students whose love of learning strengthened my faith in the future. Last but not least, I would like to thank my colleague, Professor Vitonio San Juan for his assistance in reviewing this and other articles by this author.

1. It is this sense that the dominant paradigm is shifting that gave rise to my co-optation and invocation of Alfred Lord Tennyson's "The Passing of Arthur" (Part 12 of the Idylls of the King) and its oft-quoted lines: "The order changeth, yielding place to the new ...."

2. For an analysis of the terms "human security" and "global security," see PETER J. STOETT, HuMAN AND GLOBAL SECURITY, AN EXPLORATION OF TERMS (1999). 
prospects for development in a mutually reinforcing cycle. The article also discusses the link between AIDS and conflict, focusing on the degree to which AIDS exacerbates national, regional, and global security dilemmas and undermines the international capacity to manage conflicts. ${ }^{3}$

Part III analyzes the emerging international response to the link between AIDS and security dilemmas as well as the potential ramifications for international theory and practice. With a focus on certain actions taken by the UN and the Clinton Administration, the article examines the impact of the global response on conventional understandings of the core concepts of national interest, sovereignty, and non-intervention.

The article argues that the intractable nexus between pestilence and international security precipitated a rethinking of traditional conceptions of national interest, security, and sovereignty. Mounting an effective global response to AIDS as a security issue required a re-conceptualization of national interest and security, as well as an integration of national interest and international interest. The policy proposals and pronouncements of key world leaders revealed a reflective reappraisal and critical rethinking of priorities in the throes of the pandemic - a process that sparked an unusually high level of international cooperation and engendered a new consensus about the synergy between national and international interests.

The article further contends that as the human needs/human rights concerns of AIDS victims are increasingly addressed by international organizations, the boundaries around the nation-state-reified by the institution of sovereignty - are under attack. Hitherto prohibited forms of intervention into erstwhile domestic zones ${ }^{4}$ are more tolerated, permissible, desirable, and imperative; states are modifying their conceptions of national interest to embrace a broader vision of 'world interest;' the concept of international security itself is undergoing substantial revision and

3. See International Crisis Group, HIV/AIDS as a Security Issue (2001), available at http://www.crisisweb.org/projects/issues/hiv_aids/reports/A400321_19062001.pdf (last visited June 9, 2002). See also The International Crisis Group, available at http://www.intl-crisisgroup.org/projects/showreport.cfm?reportid-321 (last visited June 9, 2002); United Nations Special Session on HIV/AIDS, Fact Sheet: AIDS as a Security Issue, available at http://www.unaids.org/fact_sheets/ungass/html/fssecurity_en.htm (last visited Sept. 20, 2002); UNAIDS Humanitarian Unit, UNAIDS Initiative on HIV/AIDS and Security, available at http://www.unaids.org/security/ Issues/human\%20security/docs/SecurityInitiative.ppt (last visited Sept. 20, 2002).

4. See U.N.CHARTER, art. 2, para. 7.

Nothing contained in the present Charter shall authorize the United Nations to intervene in matters which are essentially within the domestic jurisdiction of any state or shall require the Members to submit such matters to settlement under the present Charter; but this principle shall not prejudice the application of enforcement measures under Chapter VII. 
transformation, and the principle of non-intervention is gradually being weakened. ${ }^{5}$

In sum, the Article also argues that the global response to AIDS as a security issue was a significant challenge to the statecentric international system and a key test of its ability to develop a viable normative framework for addressing governance dilemmas catalyzed and exacerbated by runaway globalization. The Article argues that global response suggested the limits of the state-centric system, and its epistemological enabler, political realism, when it comes to resolving the challenges of the emerging global society. By the same token, the response vindicates the growing relevance of neoliberal institutionalist approaches in explaining the heightened international cooperation required to respond to dire human needs as the processes of globalization accelerate at breakneck speed.

\section{AIDS \& SECURITY}

AIDS is a security threat at both the micro-level and the macro-level, imperiling the domestic situation as well as the peace and tranquillity of international society. Due to the conterminous and mutually reinforcing symbiotic realities of HIV-pestilence, violence and security dilemmas in Africa, ${ }^{6}$ AIDS is a multidimensional security threat. The Joint United Nations Programme on HIV/AIDS (UNAIDS) ${ }^{7}$ and the International Crisis Group $\left(\right.$ ICG) ${ }^{8}$ identified several important ways in which AIDS threatens security. The pandemic is concomitantly: (1) a personal security issue; (2) an economic security issue; (3) a community security issue; (4) a national security issue; and (5) an international security issue. ${ }^{9}$ The first three above are, taxonomically, human security issues, whereas the last two are the more traditional or conventional global security issues. While these threats are discussed separately, it should be noted that they are interrelated and mutually reinforcing.

5. In a lecture at Princeton University, the author argued that much like microbial pestilence, the growing threats posed by terrorists and other violent non-state actors require a proactive and multi-level internationalist foreign policy. To protect and defend our way of life, the U.S. cannot afford to ignore seemingly local problems in 'distant' lands as these issues can fester like a sore wound and eventually wind up infecting us. Thus even as the U.S. must engage in robust and necessary self defense involving the use of force, I contend that other and equally vital dimensions of "self-defense" require perennial and preemptive assessment, engagement and intervention. I advocated a strategy that included "multiple war-heads" some to be launched against poverty, pestilence, ignorance, oppression and other factors exacerbating human insecurity. See J.M. Spectar, Lecture for the James Madison Program in American Ideals \& Institutions at Princeton University (Sept. 27, 2002).

6. See STOETT, supra note 2, at 33-34.

7. See International Crisis Group, supra note 3. See also United Nations Special Session on HIV/AIDS, supra note 3; UNAIDS Humanitarian Unit, supra note 3.

8. See UNAIDS Humanitarian Unit, supra note 3.

9. Id. 


\section{A. AIDS \& Human Security}

There is growing recognition that AIDS constitutes a serious human security threat, precipitating severe personal, social, cultural, and economic dislocations that manifest themselves on the global level. As the world awakens to this catastrophe, it is becoming even more apparent that human security is an inextricable aspect of international security. Yet, the notion of human security is itself relatively new in mainstream international political and diplomatic discourse. Commentators such as Peter Stoett have put forth a conception of human security that includes "analyses of those contemporary insecurities which affect us all, as individuals and as part of a global ecosystem." 10 The term has even found its way into the lexicon of James Wolfensohn, President of the World Bank, who has urged states to rethink their approach to security by embracing a focus on human security and its relationship to sustainable development:

Security develops from within societies. If we want to prevent violent conflict, we need a comprehensive, equitable, and inclusive approach to development. . . . Security, empowerment and opportunity must be recognized as key to freedom from poverty - just as freedom from poverty must be recognized as key to security. ${ }^{11}$

Consequently, Wolfensohn urges development and aid agencies to give careful thought to "the nature of human security."

On the human security plane, AIDS damages the individual and family, and, the disease also ravages economies and communities. ${ }^{13}$ HIV/AIDS obliterates advances in health, life expectancy, and infant mortality; imperils agricultural and food production; fractures families and communities; and robs

10. STOETT, supra note 2 , at 23.

11. Press Release, The World Bank Group, Wolfensohn Calls for "War on AIDS," available at http://wbln0018.worldbank.org/news/pressrelease.nsf/673fa6c5a2d50a67852565e 200692a79/a45ef563d190e01 e85256862005384d5? OpenDocument (last visited Dec. 31, 2002) [hereinafter Wolfensohn].

12. See id.

13. For more on the social, cultural threats posed by the pandemic, see generally J. M. Spectar, The Hydra Hath but One Head: The Socio-Cultural Dimensions of the AIDS Epidemic \& Women's Right to Health, 21 B.C. THIRD WORLD L.J. 1 (2001) [hereinafter Spectar, Hydra Hath but One Head]. With respect to the economic and developmental aspects of the pandemic; J. M. Spectar, The Hybrid Horseman of the Apocalypse, GA. J. INT'L \& COMP. L. 253 (2001) [hereinafter Spectar, Hybrid Horseman]; J. M. Spectar, Patent Necessity: Intellectual Property Dilemmas in the Biotech Domain \& Treaty Equity for Developing Countries, 24 Hous. J. INT'L L. 227 (2002) [hereinafter Spectar, Patent Necessity]. 
young people of a "viable future." ${ }^{4}$ As a result of AIDS, average life expectancy in sub-Saharan Africa has declined from about sixty-seven years to forty-seven years. ${ }^{15}$ Thus, instead of reaching and exceeding the mid sixties by 2010-2015, as would have occurred in the absence of AIDS, life expectancy will regress on average to forty-seven years. ${ }^{16}$ In addition, personal household income has fallen by as much as $25 \%$ in certain areas in a continent where three-quarters of the people are surviving on less than $\$ 2$ per day. ${ }^{17}$

The pandemic is having a particularly brutal impact on Africa's children and their prospects or dreams for a better future. Child mortality rates are rising in countries with a high prevalence rate. For instance, up to $70 \%$ of deaths of Zimbabwean children under five is attributable to AIDS. ${ }^{18}$ In 1998, nine out of ten children under fifteen that were infected with AIDS were Africans. Additionally, about $95 \%$ of all AIDS orphans have been African. ${ }^{19}$ More than one child in every ten has lost a mother to AIDS, and, by 2010, there will be about forty million orphans in sub-Saharan Africa largely because of AIDS. ${ }^{20}$

As a consequence of these threats to personal security, fissures between social and ethnic groupings may be worsened thus potentially undermining the overall security situation. ${ }^{21}$ Additionally, as AIDS manifests itself as a threat to personal security, there may be an upsurge of economic migrants and refugees. ${ }^{22}$ Furthermore, children without jobs and prospects are more susceptible to joining or being forced to join local paramilitary groups. ${ }^{23}$

14. See International Crisis Group, supra note 3; Spectar, Hybrid Horseman, supra note 13, at 258-68 (discussing the pernicious cycle between poverty, social insecurity, and pestilence).

15. UNAIDS, AIDS Epidemic Update - December 2001, available at http://www.unaids.org/worldaidsday/2001/ Epiupdate2001/Epiupdate2001en.pdf (last visited Jan. 2002) [hereinafter AIDS Update - 2001] (bi-annual report prepared by the Joint United Nations Programme on HIV/AIDS).

16. UNAIDS, AIDS Epidemic Update - December 1998, available at http://www.unaids.org (last visited Jan. 2, 2002) [hereinafter AIDS Update - 1998]. In the nine countries with an adult prevalence rate exceeding 10\% (Botswana, Kenya, Malawi, Mozambique, Namibia, Rwanda, South Africa, Zambia, and Zimbabwe), projections reveal AIDS will on average cost them at least seventeen years of life expectancy. See id. For example, today, the average child bom in Botswana has a life expectancy of forty-one years, when without AIDS, the life expectancy would be seventy years. See Kofi A. Annan, "We the Peoples," The Role of the United Nations in the Twenty-First Century, U.N. Sales No. E. 00.I.16 (2000), available at http://www.un.org/millennium/sg/report/full.htm (last visited Dec. $31,2002)$. Largely due to AIDS, Botswana dropped twenty-six places down in the Human Development Index, a ranking of countries that considers life expectancy, wealth, and literacy. See AIDS Update - 1998.

17. AIDS Update - 2001, supra note 15.

18. See id.

19. See AIDS Update - 1998, supra note 16, at 3.

20. See Annan, supra note 16, at 27.

21. See International Crisis Group, supra note 3.

22. See id.

23. See id. 
As an economic threat, the pandemic is having a devastating impact on Africa's economy and development prospects. ${ }^{24}$ The pandemic imperils human capital and natural resource development as well as business investment-the critical pillars of national economies. ${ }^{25}$ The Joint United Nations Programme on HIV/AIDS (UNAIDS) has dubbed AIDS a "destabilizing factor" because as parents and workers are felled by disease, the "structures and divisions of labour in households, families, workplaces and communities are disrupted."26 This especially impacts women in developing countries who bear additional burdens due to these dislocations and disruptions. ${ }^{27}$

AIDS also reduces income levels, impedes economic growth, and damages the social fabric. ${ }^{28}$ The pandemic has led to a spate of absenteeism, lower productivity, higher overtime costs, escalating death benefits, excessive health expenditures, ${ }^{29}$ and additional costs for recruiting and training new employees to replace the dead and dying. ${ }^{30}$

As AIDS attacks the nerve centers of Africa's economy, the impact on the labor pool or human capital is particularly far reaching. Since AIDS in Africa kills most of the victims in their productive years (ages twenty-five to forty-four) the pandemic has attenuated the class of skilled labor such as teachers, ${ }^{31}$ doctors, nurses, small business owners, and other members of the managerial and professional elite. ${ }^{32}$ In the most affected African countries, the labor pool is expected to be $10-22 \%$ smaller, reducing the workforce by about 11.5 million persons. ${ }^{33}$

The pandemic is rapidly decimating key sectors in African economies such as agriculture, mining, and transportation. ${ }^{34}$ Agricultural output is increasingly in jeopardy as millions of farm workers have died and continue

24. See, e.g., Spectar, Hybrid Horseman, supra note 13.

25. See International Crisis Group, supra note 3. See also Spectar, Hybrid Horseman, supra note 13.

26. United Nations Special Session on HIV/AIDS, supra note 3.

27. See id. See also Audry R. Chapman, Conceptualizing the Right to Health: A Violations Approach, 65 TENN. L. REV 389, 407-08 (1998) (noting the relative "disempowerment" of women in developing countries and the additional dangers they are exposed to as a result of their relatively "low status").

28. See United Nations Special Session on HIV/AIDS, supra note 3.

29. See Annan, supra note 16, at 27. For example, government forecasts in Zimbabwe indicate that about $60 \%$ of the health budget will be consumed by HIV/AIDS. See id.

30. See UNAIDS, AIDS Epidemic Update - December 1999, 5, available at http://www.unaids.org/ [hereinafter AIDS Update- 1999]. See also Spectar, Hybrid Horseman, supra note 13 , at 261.

31. See Annan, supra note 16, at 27. In Côte d'Ivoire, a teacher dies of AIDS every school day. See id.

32. See Spectar, Hybrid Horseman, supra note 13, at 262-63.

33. See International Crisis Group, supra note 3, at 9. See also Spectar, Hybrid Horseman, supra note 13, at 262 (noting that a worsening AIDS pandemic triggered a teacher shortage in Central Africa).

34. See International Crisis Group, supra note 3, at 11. 
to die from AIDS-related causes. ${ }^{39}$ A United Nations FAO report indicates seven million farm workers have died from AIDS-related causes since 1985 and sixteen million more are expected to succumb to the virus in the next two decades. ${ }^{36}$ Business investment and revenues have fallen dramatically, and there is evidence that companies are leaving Africa because of the impact of AIDS. ${ }^{37}$

Economists studying the impact of the pandemic calculate that the diminishing labor pool, along with rising welfare costs, reduced spending power, and lost investment opportunities are reducing the annual per capita growth in Sub-Saharan Africa by $0.5-1.2 \% .^{38}$ It is estimated that the impact of AIDS-related illnesses will continue to reduce the rate of growth in Africa by about $1.4 \%$ each year for the next two decades. ${ }^{39}$ Some estimates even indicate gross domestic product (GDP) could shrink up to $2 \%$ annually in certain countries with a prevalence rate higher than $20 \%{ }^{40}$ If the loss of economic output continues to accumulate, it is estimated that high prevalence countries (including some of Africa's most industrialized states) could lose over $20 \%$ of GDP by $2020 .^{41}$

AIDS is also a threat to community security because the threats to personal and economic security are also "threats to community and social cohesion." ${ }^{42}$ It is feared that the burgeoning hordes afflicted by AIDS-induced poverty and dispossession may resort to crime. ${ }^{43}$

The threat of instability is further exacerbated as the pandemic weakens state institutions and undermines the possibility of good governance by affecting civil servants and government officials in the military, the police, and the judiciary. ${ }^{44}$ The absence of effective state institutions to arrest the

35. See AIDS Update - 2001, supra note 15.

36. See id.

37. See International Crisis Group, supra note 3, at 12 (citing HIV/AIDS: THE IMPACT ON SOCIAL AND ECONOMIC DEVELOPMENT, THIRD REPORT, 2001, HC-354-I) [hereinafter IMPACT, THIRD REPORT].

38. See AIDS Update - 2001, supra note 15.

39. See Jon Peter, AIDS Sickening African Economies, WASH. PosT, Dec. 12, 1999, at A1-2.

40. See United Nations Special Session on HIV/AIDS, supra note 3, at 5. Similarly, a U.S. National Intelligence Council report reveals that in the most badly affected areas of Africa, AIDS has reduced GDP by one percentage point. See id. at 9.

41. See International Crisis Group, supra note 3, at 5. See also AIDS Update - 2001, supra note 15, at 5; Peter, supra note 39.

42. International Crisis Group, supra note 3, at 14. See also Spectar, Hybrid Horseman, supra note 13, at 265-66 (noting that the pandemic's extraordinarily harsh impact on the younger generation could fuel instability and unrest).

43. See International Crisis Group, supra note 3, at 14.

44. See United Nations Special Session on HIV/AIDS, supra note 3, at 5. Between 19982000 , three-quarters of all fatalities in the Kenyan police force were reportedly due to AIDS. See AIDS Accounts for 75\% of Police Officers Deaths, NATION, Nov. 27, 2000, at 14, available at http://www.nationaudio.com/News/DailyNation/27112000/ News/News16.html (last visited Dec. 31, 2002). See also Peter Chalk \& Jennifer Brower, Infectious Disease and the Threat to National Security, JANE's INTELLIGENCE REVIEW, Sept. 1, 2001. 
pandemic may result in social and political instability. ${ }^{45}$ As the World Bank observes, "In countries where the state is weak or has ceased to exist, the long history of militarisation has brought about a gradual diffusion of violence through the splintering of official militaries and the emergence of guerrillas and warlords." 46 As people perceive their governments are failing or have failed to solve the problem, the level of discontent may rise further. ${ }^{47}$ According to a British House of Commons report, "Evidence suggests that in societies facing economic crisis and lack of clear political leadership the presence of AIDS with its associated stigma may cause instability. The citizens are aware of the increase in illness and death, the stigma associated with it; and lack of leadership leads to blame." ${ }^{, 48}$ In addition, as the citizenry becomes increasingly restive, the risk of "communal violence" against suspected disease carriers is increasingly likely. ${ }^{49}$

It is also increasingly apparent that AIDS thrives in conditions of socioeconomic instability and insecurity. ${ }^{50}$ Marginalized persons (migrant workers, refugees, ostracized minorities, etc.) subjected to "socioeconomic insecurity" are more susceptible to infection and are just as likely to go without treatment. ${ }^{51}$ The lack of economic security also propels some people into the sex trade and its attendant health risks. ${ }^{52}$ As the pandemic advances, it exacerbates conditions of socioeconomic instability and insecurity, thereby perpetuating a pernicious cycle of pestilence and high prevalence. ${ }^{53}$

\section{B. National \& International Security}

Given the relationship between poverty, conflict, instability, and the spiraling African AIDS pandemic, it is apparent that issues of human and global security are inextricably linked. For example, the African AIDS pandemic is a "security crisis-because it threatens not just individual citizens,

45. See United Nations Special Session on HIV/AIDS, supra note 3, at 5. See also International Crisis Group, supra note 3, at 15.

46. International Crisis Group, supra note 3 , at 15.

47. See id.

48. Id. (citing, IMPACT, THIRD REPORT, supra note 37).

49. See International Crisis Group, supra note 3, at 17.

50. See generally Spectar, Hydra Hath but One Head, supra note 13; Spectar, Hybrid Horseman, supra note 13.

51. See United Nations Special Session on HIV/AIDS, supra note 3, at 5. Additionally, it has been observed that gender inequalities in sexual relations and socio-economic status exacerbate women's vulnerability to HIV infection. See, e.g., Allyn L. Taylor, Women's Health at a Crossroad: Global Responses to HIVIAIDS, 4 HEALTH MATRIX 297, 314 (1994).

52. See United Nations Special Session on HIV/AIDS, supra note 3, at 5. As Peter Singer observes, the sex trade is often one of the few thriving businesses in post-conflict zones. See Peter Singer, AIDS and International Security, 44 SURVIVAL 145 (Issue No. 4, 2002).

53. See also United Nations Special Session on HIV/AIDS, supra note 3, at 5. See generally Spectar, Hybrid Horseman, supra note 13. 
but the very institutions that define and defend the character of a society." AIDS not only "contribute[s] to international security challenges" it tends to "undermine international capacity to solve conflicts." 55

While there are many countries outside Africa where AIDS is spreading at an alarming rate, nowhere else has AIDS become "a threat to economic, social and political stability" on the scale seen in many parts of sub-Saharan Africa. ${ }^{56}$ More specifically, AIDS is a national security threat in many African countries because it disproportionately affects military personnel, police, and peacekeepers and effectively undermining key entities that safeguard statehood. Consequently, Susan E. Rice, the former U.S. Assistant Secretary of State for African Affairs, called AIDS "the greatest threat ever to Africa's security and potential prosperity." representative to the Security Council called the pandemic "a threat to [African countries] very survival as viable nations. ${ }^{158}$

The AIDS pandemic has devastated African military personnel and thereby contributed to the weakening of national security and stability in many African countries. In some sub-Saharan African countries, the ministries of defense reported "averages of $20-40$ percent positivity within their armed services." ${ }^{59}$ Estimates indicate that as much as $50 \%$ of military personnel could be HIV positive in countries with adult prevalence rates higher than $20 \%{ }^{60}$ It is not uncommon for prevalence rates in the military to far exceed civilian rates. For example, a 1998 UNAIDS report entitled "AIDS and the Military" noted that HIV infection rates among the military in Zimbabwe and Cameroon are three to four times higher than in the civilian population. ${ }^{61}$

54. Vice President Al Gore, Remarks delivered to the U.N. Security Council Session on AIDS in Africa (Jan. 10, 2000) (transcript available at http://usinfo.state.gov/topical/ global/hiv/00011001.htm (last visited Dec. 31, 2002)).

55. See International Crisis Group, supra note 3.

56. Press Release, U.N. Secretary-General, Kofi Annan Says Efforts Must Be Part and Parcel of Work for Peace and Security in Continent (Jan. 6, 2000), available at http://www.unaids.org/whatsnew/speeches/eng/nyl00100ka.html (last visited Dec. 31, 2002). Similarly, UNAIDS maintains AIDS is rapidly becoming a "key issue for human security in sub-Saharan Africa." UNAIDS, Report on the Global HIV/AIDS Epidemic - June 2000, at 21 (2000), available at http://www.unaids.org/epidemic_update/report/Epi_report.pdf (last visited Dec. 31, 2002) [hereinafter Durban Report] (the report is also known as the Durban Report).

57. Susan E. Rice, former Assistant Secretary for African Affairs, Address at the Corporate Council on Africa Army/Navy Annual Meeting (Jan. 13, 2000) (transcript available at http://www.state.gov/www/ policy_remarks/2000/000113_rice_cca.html (last visited Dec. 31, 2002)).

58. Press Release, U.N. Security Council, Security Council Holds Debate on Impact of AIDS on Peace and Security in Africa (Jan. 10, 2000), available at http://www.un.org/News/Press/docs/2000/20000110.sc6781.doc.html (last visited Dec. 31, 2002) [hereinafter Press Release, Debate on Impact of AIDS].

59. Id. comments of Michel Duval.

60. See International Crisis Group, supra note 3, at 5.

61. DEPT. OF STATE, UNITED STATES INTERNATIONAL RESPONSE TO HIVIAIDS, 2, Dept. of State Publication No. 10589 (1999), available at http://www.state.gov/www/global/oes/ health/1999_hivaids_rpt/1999hivaids.pdf (last visited Jan. 1, 2003) [hereinafter INTERNATIONAL 
These high HIV/AIDS infection rates among military personnel could precipitate national security threats as military command structures are diminished and destroyed by the pandemic. ${ }^{62}$ The increase in HIV-infected military personnel is steadily attenuating the ability of armed forces to protect their nations and preserve civil order as well as to have access to a healthy conscription pool. ${ }^{63}$ As the disease advances, militaries are likely to experience "a debilitated leadership" and they will fail to meet military needs and commitments. ${ }^{64}$

In addition to its impact on national security, it is increasingly apparent that the pandemic is a threat to international security and stability, even if security is defined conventionally. As awareness grew about the potential impact of AIDS on international security, the pandemic was referred to variously as: a "real and present danger to world security;" 65 "the world's most dangerous insurgency;" 6 a "war more debilitating than war itself;" 67 "one of the most devastating threats ever to confront the world community;" 68 and "as

RESPONSE] (citing UNAIDS, AIDS and the Military: UNAIDS Point of View, 2 (May 1998), available at http://www.unaids.org/publications/documents/sectors/military/militarypve.pdff).

62. See id.

63. See id.

64. See id. After examination of the U.S. situation, analysts concluded the AIDS threat to U.S. military readiness and capabilities was a matter of "great concern." Id. at 47. Consequently, the U.S. started the U.S. Military HIV Research Program (USMHRP) in 1986 to minimize the impact of HIV on military readiness by monitoring the spread of HIV infection in military forces and developing methods to prevent infection. See id. The effort that included the Army, Navy, Air Force, and Marines, was billed as "a highly targeted research" focused on the U.S. military's concerns, including surveilling infection rates and studying HIV mutations worldwide, research/testing of vaccines, clinical studies to slow progression, and prevention programs. See INTERNATIONAL RESPONSE, supra note 61. The U.S. Department of Defense was also involved in efforts to protect vulnerable politico-military structures by conducting prevention-oriented military-to-military educational programs. See id. Meanwhile, the National Intelligence Council prepared national estimates on the potential impact of HIV/AIDS on military personnel around the world. See id. Similarly, Defense Intelligence Agency's Armed Forces Medical Intelligence Center (AFMIC) assessed HIV prevalence worldwide and provided forecasts about the impact of AIDS and other infectious diseases on U.S. national security interests and deployed troops. See id. at 49. The AFMIC also studied transnational health trends as well as the impact of infectious diseases on foreign military force readiness as well as on military and civilian healthcare infrastructures. See id. On the development front, the U.S. Agency for International Development (USAID) funded, through AIDS Prevention and Control (AIDSCAP), a global initiative called the Civil-Military Alliance on HIV/AIDS to provide network cooperation and information sharing opportunities among civilian and military populations worldwide. See id. at 8.

65. Vice President Al Gore, supra note 54.

66. Press Release, Debate on Impact of AIDS, supra note 58, comments of Mark Malloch Brown.

67. Id. comments of James Wolfensohn. Wolfensohn also remarked that AIDS is "a security crisis," which threatens global peace and stability, particularly on the African continent. See Wolfensohn, supra note 11.

68. Vice President Al Gore, supra note 54. 
great a security challenge as [humankind] has faced since the founding of the Security Council." 69

The pandemic threatens international security because it weakens states and heightens the potential for "increased turbulence and minor violence in the international system." ${ }^{\text {70 }}$ According to official U.S. analysis of the global AIDS situation, the pandemic "also risks becoming a major contributing factor to social and political instability in those countries with hundreds of thousands to millions of infected and affected citizens." 71 A U.S. State Department report noted that the spread of HIV/AIDS is "part of a crippling cycle affecting leadership and governance" 72 that in turn, undermines national and international security. The State Department concluded that the "collective hopes of new markets, foreign investment and stable democracies" could be threatened by the unbridled spread of HIV.$^{73}$ The State Department cited the tragedy in Rwanda and the upheaval in the countries of the former Soviet Union as exemplars that illustrate how "political instability and disease have reinforce[d] each other." ${ }^{\text {" } 4}$

AIDS is an international security threat because by striking at military personnel and limiting the pool of qualified persons for peacekeeping functions, ${ }^{75}$ the pandemic acts as "an inhibitor of international response to security problems."76 It has been observed that nations ravaged by the epidemic may not be able to "muster troops to keep peacekeeping commitments." 77

The perceived link between AIDS prevalence and UN peacekeeping activities was brought to international attention, in large part, by Richard Holbrooke, former U.S. Ambassador to the UN. Mr. Holbrooke had been raising the matter of the link between peacekeeping and HIV/AIDS since 1992 when, as a private citizen, he visited UNTAC forces in Phnom Penh

69. CNN, U.N. Security Council Adopts First Health-Only Resolution on AIDS, July 18, 2000 (quoting U.S. Ambassador Richard Holbrooke), available at http://www.cnn.com/2000/HEALTH/AIDS/07/18/un.aids/ (last visited Jan. 1, 2003) [hereinafter First Health-Only Resolution].

70. See International Crisis Group, supra note 3, at 21.

71. INTERNATIONAL RESPONSE, supra note 61, at 14.

72. Id. at 1 .

73. $I d$.

74. Id.

75. See id.

76. International Crisis Group, supra note 3, at 22.

77. Emerging Infectious Diseases Are a National Security Challenge to the United States, Bureau of Occans and International Environmental and Scientific Affairs, available at http://www.state.gov/www/policy (last visited Aug. 25, 2000) [hereinafter Emerging Infectious Disease] (redefining national security in light of the AIDS threat). See also, Ambassador Wendy R. Sherman, Emerging Infectious Diseases Are a National Security Challenge to the United States, available at http://www.state.gov/www/policy_remarks/1998/980325_ sherman_diseases.html (last visited Aug. 25, 2000). 
(Cambodia). ${ }^{78}$ Holbrooke was so "disturbed by the fact" UN troops were "spreading AIDS" " that he immediately took up the issue with members of the $\mathrm{UN}^{80}$ Upon becoming U.S. Ambassador to the UN, Holbrooke brought the issue of AIDS and peacekeepers to the forefront of the global agenda. Holbrooke told a UN Security Council gathering, that it was "a fact" and "an unpleasant truth" that due to lack of proper training, education, and prevention techniques, UN peacekeepers were "spreading AIDS inadvertently." 81 As noted that peacekeepers and other international workers "must be made to realize" that in the AIDS virus, they faced "as deadly an enemy as the traditional enemies they usually come in contact with." 82 Similarly, Dr. Peter Piot, the Executive Director of UNAIDS, told UN officials the link between HIV/AIDS and UN peacekeeping, was a "significant" problem. ${ }^{83}$

Although there are no comprehensive statistics concerning HIV and AIDS among UN peacekeepers, many believe "the process of spreading is self-evident. $"{ }^{84}$ In particular, it is alleged that peacekeepers spread AIDS through "commercial sex with civilians." ${ }^{\text {" } 5 ~ M a n y ~ o f ~ t h e ~ w o r l d ' s ~ 36,000 ~}$ itinerant peacekeepers often "attract women who are working full-time or parttime as prostitutes." 86

The purported link between AIDS and peacekeepers is strongest in Africa where the UN has deployed most of its peacekeeping operations. ${ }^{87}$ In the view of Anwarul Karim Chowdhury, Bangladesh's representative, Africa's armed forces and civilian law enforcement personnel were "slumping as AIDS took a toll on their personnel. ${ }^{188}$ Since these forces played a crucial role in

78. See Remarks Following the Security Council Vote Approving Resolution 1308, Regarding HIV and Peacekeepers, July 17,2000 (remarks by Richard C. Holbrooke), available at http://www.state.gov/www/policy_remarks/2000/000717_holbrooke_un.html (last visited July 28, 2000) [hereinafter Remarks Following Vote].

79. See id. Subsequently, Holbrooke also learned there were also some connections between UN peacekeeping activities and the prevalence of AIDS in certain African countries. See id.

80. See id. When the UN finally took up the issue in 2000, the Ambassador confessed he felt a "sense of grim satisfaction" that the Security Council had at long last, acted on a cause he had been championing for nearly a decade. Id. Richard Holbrooke's role in bringing the global AIDS pandemic to the forefront of the global agenda and in directing international attention to Africa's plight is certainly in the view of this author deserving of the highest commendations, including the Nobel Peace Prize.

81. Id.

82. First Health-Only Resolution, supra note 69.

83. Id.

84. Id.

85. UNAIDS Report, June 2000, at 50.

86. First Health-Only Resolution, supra note 69.

87. See The Causes of Conflict and the Promotion of Durable Peace and Sustainable Development in africa, REPORT OF THE SECRETARY GENERAL 9, available at http://www.un.org/ecosocdev/geninfo/afrec/sgreport/report.htm (last visited Aug. 11, 2000) [hereinafter The Causes of Conflict].

88. Press Release, Debate on Impact of AIDS, supra note 58, at 7. 
peacekeeping, "their vulnerability to infection affected the defence of the peace." 89

Due to the efforts of Holbrooke, Peter Piot and other leaders, UN members began to realize "the supreme irony" whereby the very UN peacekeepers charged with preventing conflicts, were actually spreading AIDS - "a disease even more deadly than the conflicts themselves." 90 There was a growing realization that to ensure a first rate defense, a "truly modern and effective military" had to take AIDS education and prevention "seriously." 91 It became clear that since AIDS was also a security threat, peacekeeping troops had to be as protected against "enemies like AIDS," as against conventional military foes. ${ }^{92}$

\section{Linking the AIDS Pandemic \& Conflict}

Due to a multiplicity of internal and external factors, about half of the roughly two-dozen military conflicts raging around the world are in Africa. ${ }^{93}$ At the same time, Africa has over $70 \%$ of the total HIV/AIDS cases, constituting about 28.1 million HIV-infected persons. ${ }^{94}$ The perceived conterminousness between the prevalence of conflict and the AIDS pandemic appears strongest in Africa - a continent with about half of the roughly twodozen military conflicts raging worldwide. ${ }^{95}$ In fact, Africa with just about $10 \%$ of the world's total population has over $70 \%$ of the total HIV/AIDS cases, constituting about 28.1 million persons living with the virus. ${ }^{96}$ of the 5.4 million people newly infected with AIDS in 1999, four million were Africans South of the Sahara.$^{97}$ In 1999 , over $90 \%$ of the 600,000 -plus children infected due to mother to child transmissions were from sub-Saharan Africa. ${ }^{98}$

89. Id.

90. See Remarks Following Vote, supra note 78.

91. See id.

92. Id. See also The Causes of Conflict, supra note 87.

93. See Press Release, Debate on Impact of AIDS, supra note 58, at 2.

94. See AIDS Update - 2001, supra note 15.

95. See Press Relcase, Debate on Impact of AIDS, supra note 58, at 2.

96. AIDS Update-2001, supra note 15 . The 28.1 million figure was augmented by a total of over three million new infections since the last report that had a total of about twenty-five million infections in sub Saharan Africa. See UNAIDS Report, June 2000, available at http://www.unaids.org (last visited Aug. 2000). While AIDS "threatens" every region, the pandemic is especially destructive in "a broad swath of African states, endangering millions of lives." Statement for the Record Submitted to the House Committee on Banking and Financial Services, Washington D.C. Mar. 8, 2000, available at http://www.state.gov//www.policy remarks/2000/000308_holbrooke_hiv-aids.html (last visited July 2000) (Statement submitted by Richard C. Holbrooke) [hereinafter Statement for the Record].

97. See UNAIDS Report, June 2000, supra note 96, at 8.

98. See AIDS Update - 1999, supra note 30, at 14. In the most AIDS-devastated cities of South Africa, $40 \%$ of pregnant women are HIV-positive. See Annan, supra note 16, at 27. In 1998, these mother-to-child transmissions also constituted about 5-10\% of the total new infections in developing countries. See INTERNATIONAL RESPONSE, supra note 61. 
HIV is the leading cause of death in the region, ${ }^{99}$ responsible for the deaths of over fifteen million Africans since the onset of the pandemic. ${ }^{100}$ The death toll continues to mount, particularly in sub-Saharan Africa. In 1998 alone, two million Africans died of AIDS, ten times the number who died in war. ${ }^{101}$ Three years later, the estimated death toll from AIDS in Africa was about 2.3 million ${ }^{102}$ with some estimates as high as 2.5 million. Most of these fatalities (about $85 \%$ ) occur in the crescent of states from Kenya to South Africa. ${ }^{103}$

Despite the high AIDS death toll and infection rates, it remains unclear whether the unusual virulence of AIDS in Africa is directly attributable to the prevalence of violent conflict or vice versa. Even if AIDS itself does not cause conflict, it clearly exacerbates the overall security situation and thereby contributes to atrophy and ensuing violence. In a speech to the UN Security Council, Mr. Annan summed up the nexus as follows: "The breakdown of health and education services, the obstruction of humanitarian assistance, the displacement of whole populations and a high infection rate among soldiersas in other groups which move back and forth across the continent-all these ensure that the epidemic spreads even further and faster." 104

The fiery mix of war and AIDS wrecks the lives of those least able to defend themselves in developing countries and totally frustrates the realization of fundamental human rights, including right to health. ${ }^{105}$

Africa's wars have "seriously undermined Africa's efforts to endure long-term stability, prosperity and peace for its peoples,"106 - and this is especially so in the context of the pandemic. For example, in the Democratic Republic of the Congo, where civil strife threatens the food supplies of over ten million people, ${ }^{107}$ it is no coincidence that the rate of HIV prevalence is one

99. AIDS Update - 200I, supra note 15.

100. UNAIDS Report, June 2000, supra note 96, at 7. The effect of the AIDS pandemic on Africa and the rest of the world was grossly underestimated. In 1991, estimates had predicted that by the end of the nineties, nine million sub-Saharan Africans would be infected and five million would die. See id. Yet, by 1999 UNAIDS/WHO reported that 23.3 million Africans were infected and 13.7 million Africans had died. See AIDS Update - 1999, supra note 99 at 5 .

101. See UNAIDS Report, June 2000, supra note 96, at 21.

102. See AIDS Epidemic Update - 2001, supra note 15, at 14.

103. See Statement for the Record, supra note 96.

104. Press Release, United Nations, Secretary-General Says Fight Against AIDS in Africa Immediate Priority in Global Effort Against Disease, available at http://www.unaids.org/ whatsnew/speeches/eng/ny 100100ka.html (last visited July 2, 2000) [hereinafter Press Release, Immediate Priority].

105. See generally Spectar, Hydra Hath but One Head, supra note 13. International documents guaranteeing a right to health include Article 25 of the Universal Declaration of Human Rights, G.A. Res. 217 (1948), reprinted in BASIC DOCUMENTS SUPPLEMENT TO INTERNATIONAL LAW 143 (LOUIS HENKIN et al. eds.); the WHO Constitution; and, the International Covenant on Economic, Social and Cultural Rights (G.A. Res. 2200, 21 U.N. GAOR, supp. 16, at 52, U.N. Doc. A/6316 (1967).

106. The Causes of Conflict, supra note 87.

107. See Press Release, Immediate Priority, supra note 104. 
of the highest in the world. Not surprisingly, UNAIDS concludes populations are more vulnerable in regions plagued by "famine, repression or violent conflict and war."108 The ensuing social dislocation and disruption "create fertile settings for HIV transmission." 109 The United Nations Children's Emergency Fund (UNICEF) estimates that in African wars, food and medical shortages, along with "the stress of flight," have killed about twenty times more persons than all the armaments combined. ${ }^{110}$

The atrocities of war also have a particularly damaging impact on children's access to health as they "provoke displacement, aggravate levels of malnutrition and risks of disease, separate children from their families . . . exacerbate pre-existing discrimination of girls and minorities, and vastly reduce access to education and health services." 11 Additionally, children unable to escape conflict zones face forced military recruitment and prostitution, both of which expose such children to premature and dangerous sexual activity with high seropositive persons. ${ }^{12}$ Children in refugee camps are also more likely to engage in sexual activity earlier, often without access to health education and HIV-prevention services. ${ }^{113}$ Ironically, the main perpetrators of sexual violence in conflict situations are often themselves boyscum-men who staff various official and unofficial armed units. ${ }^{114}$

As Michel Duval, the Canadian representative to the UN has observed, attempts by African governments to check the spread of AIDS are "hampered by civil strife, refugee flows, rapid urbanization and poverty; each of which, in turn, contributed to further spread of HIV/AIDS." "is In particular, war can disrupt progress in a comprehensive plan to fight AIDS-as reportedly happened in the Democratic Republic of Congo, where "widespread pillaging" put an end to the anti-AIDS campaign. ${ }^{116}$ As governments fail, or are chronically weakened, health systems falter rapidly, leaving populations increasingly prone to illness and even further economic decline. ${ }^{117}$ In societies wracked by instability, this "cocktail of disasters is a sure recipe for more conflict," that in turn "provides fertile ground for further infections." 118 Additionally, AIDS overwhelms health systems by destroying the basic fabric of entire societies and precipitating "an unprecedented degree of gloom and

108. Fact Sheet, AIDS as a Security Issue, supra note 3, at 5.

109. Id.

110. Stuart Malsen, Symposium: Implementation of the United Nations Convention on the Rights of the Child, 6 TRANSNAT'LL. \& CONTEMP. PROBS. 329, 330 (1996). Between 1986 and 1996, two million children died as a result of war alone. See id.

111. Id.

112. See Fact Sheet, AIDS as a Security Issue, supra note 3, at 5.

113. See id.

114. See id.

115. Press Release, Debate on Impact of AIDS, supra note 58, at 10.

116. See id. at 19.

117. See INTERNATIONAL RESPONSE, supra note 61 (National Interest Strategy).

118. Press Release, Immediate Priority, supra note 104. 
despair." 119 Such conditions of utter hopelessness are in actuality are some of the "most virulent seeds of conflict." 120

It is believed that the displacement of people associated with military conflict and civil unrest in sub-Saharan Africa may be spreading the epidemic. ${ }^{121}$ Conflicts accelerate the spread of HIV/AIDS because "soldiers and displaced civilians on the move [are] important sources for disease dissemination."122 The spiraling rate of infection in Rwanda after 1997, has been attributed to the "huge population movements" during and immediately after the years of ethnic strife. ${ }^{123}$ Before the turmoil of the mid-1990s, relatively extensive surveillance of the HIV epidemic in Rwanda revealed a familiar pattern of infection: high rates in urban areas, but far lower rates (about $1 \%$ ) in rural areas which were home to the bulk of the population. ${ }^{124}$ The Rwandan conflict, and the consequent mass migrations, ${ }^{125}$ "changed the shape of the epidemic," leading to higher infection rates, particularly in rural areas. ${ }^{126}$ By 1997 , survey results indicated an overall Rwandan infection rate of just over $11 \%$, with "little difference" between urban and rural areas. ${ }^{127}$ Among teenagers, infection was higher in rural areas than in cities, with up to $4 \%$ of twelve-fourteen year olds HIV-positive. ${ }^{128}$ Furthermore, migrants who had spent years of conflict outside Rwanda had lower rates of infection than those who had been trapped in the internecine conflict. ${ }^{129}$ HIV prevalence among Rwandans who had spent the conflict years in refugee camps was about $8.5 \%$. Many of these people had fled from rural areas where the pre-conflict HIV rate was about $1.3 \% .{ }^{130}$ Similarly, a significant increase among pregnant women in Luanda, Angola, is believed to be linked to the displacement of people precipitated by the Angolan civil war. ${ }^{131}$

119. Press Release, Debate on Impact of AIDS, supra note 58, at 9 (comments of Mr. Peter Van Walsum, Netherlands). Gelson Fonseca of Brazil echoed these comments, noting that the destruction engendered by AIDS leads to a climate of "despair and disarray that fuelled conflicts" Id. at 14.

120. Press Release, Debate on Impact of AIDS, supra note 58, at 9.

121. See AIDS: A Challenge for Government, available at http://worldbank.org/aidsecon/confront/confrontfull/ chapter1/chap1.html (last visited July 2000).

122. Press Release, Debate on Impact of AIDS, supra note 58, at 9 (according to Peter Van Walsum, representative of the Netherlands).

123. AIDS Update - 1998, supra note 16, at 12.

124. See id.

125. See id. About $75 \%$ of the 4700 people surveyed after the conflict in 1997 had lived elsewhere between 1994-1997, an "astonishingly high turnover" for a largely rural country. See id.

126. See id.

127. See id.

128. See AIDS Update - 1998, supra note 16, at 12.

129. See id. In particular, migrants returning from countries with "relatively strong" prevention campaigns such as Uganda and Tanzania had lower rates of HIV infection than those who had endured the strife. See id.

130. See id.

131. See Report on the Global HIV/AIDS Epidemic 2000, available at www.unaids.org, (last visited Sept. 20, 2002). 
Massive refugee flows and long-term refugee camps have "severe social and environmental consequences" inimical to health and security. ${ }^{132}$ The dramatic increase in HIV/AIDS prevalence in many refugee camps is fueled by dismal social conditions, including "overcrowding, violence, rape, despair and the need to sell or give away sex to survive."133 Additionally, the AIDS crisis in the Congo was reportedly "exacerbated" by the millions of Rwandan refugees who poured into the country. ${ }^{134}$

Sudden and/or massive refugee flows have the potential of undermining the stability of the host states. The situation is especially grave when already marginal and unstable states are overwhelmed by large numbers of refugees "mingled with (fleeing) combatants." 135 For example, in the African Great Lakes area, the mingling of combatant and non-combatant refugees following the upheavals in Somalia and elsewhere, destabilized neighboring Zaire and other countries. ${ }^{136}$

The impact of huge refugee inflows on health and social well-being is particularly pronounced in Guinea-a country with the highest per capita refugee population worldwide. ${ }^{137}$ About $10 \%$ of the population is war refugees fleeing Sierra Leone and Liberia, ${ }^{138}$ and their presence is creating significant dislocations with implications for overall health and well-being. These "longterm" refugees have had a profound effect on Guinea's economy and resource by fueling rising unemployment and increasing the number of street children. ${ }^{139}$ Additionally, the burden on local infrastructure including hospitals and sanitation facilities has been considerable. ${ }^{140}$ Thus, refugee flows associated with these conflicts tend to create conditions conducive to the rapid spread of HIV. ${ }^{141}$

Meanwhile, military conflict and civil unrest may be spreading the epidemic ${ }^{142}$ when rape is used as an instrument of war. ${ }^{143}$ In some cases, rape has been used as a weapon of war "to humiliate and control the behaviour of civilian populations or to weaken the enemy by destroying the bonds of family

132. See The Causes of Conflict, supra note 87.

133. AIDS Update - 1998, supra note 16, at 12.

134. See Press Release, Debate on Impact of AIDS, supra note 58, at 19.

135. See The Causes of Conflict, supra note 87.

136. See id.

137. See id.

138. See id.

139. See id.

140. See id.

141. See INTERNATIONAL RESPONSE, supra note 61 (National Interest Strategy).

142. See AIDS: A Challenge for Government, supra note 121.

143. See UNAIDS Report, June 2000, supra note 96, at 50 (noting that combatants frequently use rape as a weapon of war, thus increasing the likelihood of spreading the virus that causes AIDS and other STDs). See id. 
and society." 144 The probability of HIV infection after rape by military men appears to be higher, since surveys show that in most countries STD infection rates among the military are about two to five times higher than those in comparable civilian populations. ${ }^{145}$ In fact some sub-Saharan ministries of defense reportedly have "averages of 20 to 40 percent within their armed services."146

It is increasingly apparent that persons trapped in conflict and refugee situations "may have little control over their exposure to HIV and even to sex." 147 Ileka Atoki, the Congolese representative to the UN, claimed that during the Congo conflict, ${ }^{148}$ the Ugandan military "sent into the field seropositive soldiers who raped women and girls in the occupied areas, causing HIV infection to increase exponentially." 49 Similarly, rape both inside and outside refugee camps has played a role in spreading HIV in the war torn areas of Rwanda, Ethiopia, and Somalia. ${ }^{150} \mathrm{~A}$ random survey of Ethiopian refugees in a camp in Somalia in 1986 revealed that seventeen knew someone in their village, and, thirteen knew someone in their family who had been raped by the Ethiopian militia. ${ }^{151}$ Similarly, over half of Rwandan women who reported they had been raped stated the rape occurred during the course of the conflict. ${ }^{152}$ Women and young girls raped by military men suffer more than just the immediate physical and psychological trauma: they are tragically exposed to a much higher risk of HIV/STD infections as the forcible, unprotected sex often leads to torn vaginal or anal tissue, creating an easy entry point for the virus. ${ }^{153}$ Among Rwandan women who had been raped, $17 \%$ were HIV-positive, as compared with $11 \%$ who had not. Additionally,

144. See id. at 50. In Bangladesh's struggle for independence, 250,000 women were raped, resulting in about 25,000 pregnancies; $39 \%$ of Vietnamese boat women aged eleven-forty were abducted or raped at sea in 1985 . See id.

145. See id. at 61.

146. Press Release, Debate on Impact of AIDS, supra note 58, at 10 (citing Michel Duval, Canadian representative at the UN).

147. AIDS Update - 1998, supra note 16, at 11.

148. Given that up to nine African countries were at various times involved in the Congo conflict, some have referred to the conflict as Africa's first World War.

149. Press Release, Debate on Impact of AIDS, supra note 58, at 19.

150. See AIDS Update - 1998, supra note 16, at 12 (noting that rape has "doubtless played a part in spreading the virus in Rwanda). The use of rape as a tool of war gives great urgency to the matter of a robust, effective and well-resourced international criminal court. See id. In that regard, it is necessary that all states sign and ratify the Rome Statute of the International Criminal Court, U.N. Diplomatic Conf. of the Plenipotentiaries on the Establishment of an ICC, U.N. Doc. AVCONF.183/9 (1998) (providing that rape, sexual slavery, enforced prostitution, forced pregnancy, enforced sterilization and other forms of sexual violence are "war crimes" when perpetrated during armed conflicts, and, may in certain cases be deemed "crimes against humanity").

151. See UNAIDS Report, June 2000, supra note 96 , at 50.

152. See AIDS Update - 1998, supra note 16, at 12. (According to the survey, $3.2 \%$ of Rwandan women had been raped).

153. See UNAIDS Report, June 2000, supra note 96 , at 51. 
female rape victims were three times as likely as those who were not raped to be afflicted with genital sores. ${ }^{154}$

In sum, the pandemic is demonstrating that the health of nations is integrally or intricately connected to the level of security or stability in a mutually reinforcing interactive relationship. ${ }^{155}$ As governments channel disproportionate resources to war making, there is little left to allocate to the creation of social and economic safety nets required to realize the right to health. The UN Secretary General Mr. Kofi Annan summed up the situation as follows:

By overwhelming the continent's health services, by creating millions of orphans and by decimating health workers and teachers, AIDS is causing social and economic crises which in turn threaten political stability. It also threatens good governance, through high death rates among the elites, both public and private. And high infection rates in the police and armed forces leave African States ill equipped to face security threats. ${ }^{156}$

The dovetailing of the human security threats and their impact on the national and international policies illustrates a new type of three-level game, ${ }^{157}$ marked by fluid interactions of the personal, the national and the international levels. By blurring the distinction between matters of local versus global concern, AIDS is a "human security" dilemma that is simultaneously a global security issue.

II. The Global ReSPONSE \& IMPLiCations FOR INTERNATIONAL LAW, POLITICS \& DIPLOMACY: RETHINKING NATIONAL INTEREST, SOVEREIGNTY \& INTERVENTION

This section of the article examines the international response to the link between AIDS and security dilemmas, and it analyzes the implications for conceptions of national interest, sovereignty and intervention. Focusing particularly on the transformational leadership of the Clinton presidency ${ }^{158}$ as

154. See AIDS Update - 1998, supra note 16 , at 12.

155. The relationship between health and security is not new. Historians speculate that ill health in Rome fueled, in part, by the lead pipes used in Roman aqueducts was partially responsible for a spate of debilitating maladies that afflicted Rome's plutocrats, thus fueling the decline of that empire.

156. Press Release, Immediate Priority, supra note 104.

157. See generally Bob Putnam's analysis of two-level games in Robert D. Putnam, Diplomacy and Domestic Politics: The Logic of Two-Level Games, 42:3 INT'LORG. (1988).

158. Although the emphasis here is an examination of the Clinton Administration's policies in the period of intense international diplomatic activity leading to the UN resolution on HIV/AIDS (1995-2000), the article will also include a synopsis of the Bush II policies on 
well as the UN Security Council resolution on HIV/AIDS, the article argues that a new consensus has emerged regarding the governance of global threats, such as AIDS. These new understandings integrate more seamlessly the national and the international interest with respect to the globalization of health. In addition, the heightened international coordination and cooperation on the AIDS problem is best explained by neoliberal institutionalist approaches as opposed to conventional realism.

At first, the world reacted to the unfolding pandemic with a mixture of denial and defeatist despair. ${ }^{159}$ The initial global response to the AIDS pandemic was slow, uncoordinated and many international agencies bickered with each other over turf. ${ }^{160}$ In particular, many African governments were demobilized by a paroxysm of debilitating denial about the scale of the pandemic unfolding before them. ${ }^{161}$ Additionally, for the first decade of the epidemic, HIV/AIDS was viewed as a health issue affecting mostly gays and drug users. ${ }^{162}$ To the chagrin of AIDS and human rights activists, a deafening silence enveloped the pandemic, as millions died around the world. ${ }^{163}$

Nevertheless, after being ignored or denied by many members of the international community during much of the eighties, the global AIDS pandemic and its wide-ranging ramifications have emerged as a key issue at the forefront of the global agenda. By the early nineties, African governments began to recognize HIV as "a real threat to the continent's future." 164 To affirm their seriousness, African leaders meeting at an OAU summit committed themselves to "exert all possible means to limit the spread and impact of the scourge." 165 The recognition of the ravaging AIDS pandemic as a security threat has created even more international attention, sparking "a new surge of momentum" and "a wide-range of action to fight AIDS around the world."166

The U.S. administration of William Clinton took a leadership role in rethinking and redefining U.S. national interests regarding international health, as well as in spurring a new global consensus about responding to AIDS as a security threat. Most significantly, the United States steered the Security Council towards the passage of a seminal resolution that crystallized and

AIDS in Africa. See infra at part III. For an analysis of the impact of presidential change on international law see J.M. Spectar, Elephants, Donkeys or Other Creatures? Presidential Election Cycles \& International Law of the Global Commons, 15 AM. U. INT'L L. REv. 975 (2000).

159. See Spectar, Hybrid Horseman, supra note 13, at 272-73.

160. See id.

161. See id.

162. See id.

163. See id.

164. Press Release, Debate on Impact of AIDS, supra note 58, at 20 (statement of Ibra Deguene Ka, noting that the 1992 OAU Summit had adopted a resolution on the threat of AIDS).

165. Id.

166. Statement for the Record, supra note 96 (reporting a conversation with Mr. Peter Piot, head of UNAIDS, the UN's principal agency for fighting AIDS). 
reflected the new global consensus on international health in a new era of accelerated globalization. Below, the article examines how the new global consensus about HIV-pestilence, as crystallized in large measure by the Council's resolution warrants a rethinking of several core concepts of international theory and practice, including concepts of national interest, security, sovereignty and the associated concept of non-intervention.

\section{A. National Interest \& National Security}

National interest has often served as rationalization for the choices of statesmen, including their choice of particularly unpleasant courses of action. It appears as if the mere authoritative invocation of "national interest" by a statesperson is sufficient to chill debate on foreign policy questions and to affix the imprimatur of legitimacy on all actions, even including those that contravene principles of international law. Nonetheless, despite its common usage, the concept is often misunderstood. A particularly prevalent misconception relates to the frequent attribution of a reified and concrete meaning to the concept - a semantic transubstantiation that suggests orderings of national interest are largely impervious to the international ecosystem. After a brief examination of the historical meanings of the concept, the author will explore the case of the United States' response to AIDS to illustrate the process of re-conceptualization of national interest and the emergence of a new consensus about core priorities, values and interests. The article also argues that this re-conceptualization is best explained by neoliberal approaches that embrace the modification of core realist ${ }^{167}$ variables as a result of continuous engagement in coordinated activity in response to a common problem.

Traditional understandings of national interest and security are anchored to the realist doxology of international relations. Realism, which has been traced back to Machiavelli's politico-historical analyses, made its American debut in the work of Hans Morgenthau and Kenneth Waltz. ${ }^{168}$ Since Machiavelli's seminal work about princely statecraft, national interest has been a sacerdotal pillar of foreign policy, rationalizing a potpourri of actions and inactions. Neo-realism has three fundamental properties: the nature of man is characterized by an endless desire for increasingly more power; all states regardless of their size or capability are identical in their fixation regarding a specific concept of national interest as a guide to their actions; and the nature of the state system imposes rational constraints on the unrestrained pursuit of conflicting national interests via the balance of power. ${ }^{169}$

167. See definition of realism infra.

168. See Robert W. Cox, Social Forces, States and World Orders: Beyond International Relations Theory, in FRIEDRICH KRATOCHWIL \& EDWARD D. MANSFIELD, INTERNATIONAL ORGANIZATION A READER 343, 347 (1994).

169. See id. at 347. American realism, or neo-realism, is the "ideological form abstracted from the real historical framework imposed by the Cold War." Id. 
As neo-realism developed into a problem-solving theory, history became a mere "quarry providing [the] materials" to demonstrate predictable variations on persistently recurring themes. ${ }^{170}$ The approach, which became increasingly ahistorical, "dictates that, with respect to essentials, the future will always be like the past." 171 Notwithstanding its purported value neutrality, neo-realism is also embedded with an inherent normativity and performs a "proselytizing function": the theory rests on the assumption that given the experiences of all actors within the system, they will all adopt the neo-realist formula as a road map. $^{172}$

Intrinsic to the neo-realist dogma is the notion that states act out of wellarticulated and rationally derived interests in a process of calculation that is uninfluenced by moral or humanistic considerations. Waltz sums up the neorealist conception of national interest as follows:

[T]o say that a country acts according to its national interest means that, having examined its security requirements, it tries to meet them ... Entailed in the concept of national interest is the notion that diplomatic and military moves must at times be carefully planned lest the survival of the state be in jeopardy. ${ }^{173}$

For Waltz, the "elusive notion of national interest" is made clearer by comparing nations and corporations: the latter presumably "seek to maximize expected returns" while the former "strive to secure their survival." 174 Nonetheless, despite this "assumed interest" it is difficult to generate "useful inferences" unless one can determine what steps are necessary for successful pursuit of the articulated interest. ${ }^{175}$ Thus, to say a state seeks its own preservation or pursues its national interest is much more compelling if one can determine just what actions are necessitated by national interest. ${ }^{176}$ As each state exercises its prerogative of choosing its own policies, choosing "effectively requires

170. Id.

171. Id. (noting that the eighteenth century Neapolitan idealist, Giambattista Vico, criticized the "conceit of scholars" who purport that "what they know is as old as the world."). $I d$. at 348. It is equally wrong-headed to take a doctrine from one historical epoch and from a particular structure of international relations and to hold it up as universally true. See Cox, supra note 168 , at 348 .

172. See id.

173. See Kenneth N. Waltz, Theory Of INTERnational Polttics 134 (1979).

174. Id. at 134. On the significance of self interestedness, both neorealists and neoliberals are in concurrence. See Alexander Wendt, Anachy Is What States Make of It: The Social Construction of Power Politics, in KRATOCHWIL \& MANSFIELD, supra note 168, at 77, 77. Neorealists [as well as neoliberals] postulate the "self-interested state as the starting point for theory." See id. They assume states are the principal actors in the international system and they both conceptualize security in "self-interested terms." Id.

175. See WALTZ, supra note 173 , at 134.

176. See id. (Both neorealist and neo-liberal rationalistic approaches treat the interests of state agents as "exogenously given" and they primarily examine how "the behavior of agents generates outcomes"). See Wendt, supra note 174, at 77. 
considering the ends of the state in relation to its situation." 177 Even as large states are constrained by their situations, they are just as able to act to affect them. ${ }^{178}$

The traditional neorealist approach to national interest takes a sober view of the possibility of cooperative politics in an anarchic system marked by a naked propensity to self-help and self-promotion. The anarchic, ipso facto, self-help system, is also marked by a dearth of "central authority and collective security," thus leading to the "inherently competitive dynamics of the security dilemma and the collective action problem." ${ }^{179}$ Given the prevailing conditions of self-help, state survival is the primordial value as "survival is a prerequisite to the achievement of other ends. ${ }^{" 180}$ In pursuit of self-interest, a state calculates its actions according to the situation in which it finds itself ${ }^{181}$ Thus, relative gains could be more significant than absolute ones because one's gain counter-balanced against others', impacts the ability to shift for oneself. ${ }^{182}$

Under the competitive neorealist schema, only "simple learning or behavioral adaptation is possible; the complex learning involved in redefinitions of identity and interest is not." ${ }^{2183}$ Thus, in hobbesian ${ }^{184}$ "competitive" schema (as well as in neoliberal "individualistic" security systems) power politics is inherently about "efforts to manipulate others to satisfy self-regarding interests." 185

However, realist conceptions of national interest fail to capture the dynamic process of reflectivity about the interest matrix, particularly in institutionally-bounded settings where coordination is imperative. The fact of interest re-conceptualization within the context of patterned interactions is more adequately accounted for in neoliberal institutionalist approaches. Unlike neo-realism, which tends to ascribe a "low value on the normative and institutional aspects of world order," optimistic about the possibility of warm cooperation; additionally, neo-liberal internationalism neither excludes moral goals nor reduces everything to power equations. ${ }^{187}$ Neoliberals challenge the realists' dim view of cooperation arguing that "process can generate cooperative behavior," and that interests and identities can be transformed. ${ }^{188}$ Neo-liberal institutionalists reject the notion of fixed exogenously structured interests, citing concepts such as

177. See WALTZ, supra note 173 , at 134.

178. Id.

179. Wendt, supra note 174 , at 77 .

180. WALTZ, supra note 173 , at 134 .

181. See id.

182. See id.

183. Wendt, supra note 174 , at 77 .

184. Hobbes' Leviathan is often considered a precursor to modern realism.

185. Wendt, supra note 174 , at 81 . In neoliberal individualistic systems, states are mostly concerned with absolute rather than relative gains and collective action is more feasible despite the threat of egoistic free riders. See id.

186. Cox, supra note 168 , at 352 .

187. See id. at 348.

188. See Wendt, supra note 174 , at 78 . 
"complex learning" [Joseph Nye], "changing conceptions of self and interest" [Robert Jervis] and "sociological conceptions of interest." [Robert Keohane]. ${ }^{189}$

In effect, neoliberal institutionalist approaches assume that "institutions transform identities and interests," particularly within a milieu of "relatively stable practice." 190 Thus, within the context of patterned and reciprocal interactions, actors' identities shape or determine their interests. That is, actors do not perpetually carry an unchanging "portfolio of interests" that they cling to "independent of social context"; rather, actors continually or periodically reassess and "[re]define their identities in the process of defining situations." Interests are defined through processes of "reciprocal interaction" and are "constituted by collective meanings" within "relatively stable social [institutional] structures." 192

The process of creating institutions goes beyond imposing external constraints on the actions of exogenously constituted actors: it encompasses an internalization of "new understandings of self and other, of acquiring new role identities." process whereby expectations generated by patterned interaction transform identities and interests. ${ }^{194}$ This contrasts sharply with game theoretic analyses of cooperation wherein identities and interests that constitute the structure of

189. Id. Elsewhere, this writer has discussed the role of epistemic communities in redefinition of interests and values. See J.M. Spectar, Saving the Ice Princess: NGOs, Antarctica \& International Law in the New Millennium, 23 SUFFOLK TRANS. NAT'LL REV. 58, 96-99 (1999) [hereinafter Spectar, Saving the Ice Princess]. See also Peter Haas, Introduction: Epistemic Communities and International Policy Coordination, 46 INT'L ORG. 1, 3 (1990); Peter Haas, Do Regimes Matter? in KRATOCHWIL \& MANSFIELD, supra note 168, at 128, 13337.

190. Wendt, supra note 174 , at 85 .

191. Id. at 80. Identity is an inherently "role-specific understanding and expectation about self" that exists "within a specific, socially constructed world." Id. at 83.

192. Id. at 83 (emphasis added). These patterned interactions between transnational elites, enmeshed in an interactive network of rules, principles and norms, constitute the substratum of a vibrant Grotian international order. See Stephen Krasner, Structural Causes and Regimes Consequences: Regimes as Intervening Variables, in KRATOCHWIL \& MANSFIELD, supra note 168 , at 97,101 . An on-going interaction may become "embedded in a broader social environment that nurtures and sustains" the preconditions for its operation. Id. at 100-01. These "complex [and] persistent patterns" of interaction eventually become suffused with "normative significance" giving rise to regimes. Id. at 99. (Regimes are thus defined as "sets of implicit or explicit norms, rules, decision-making procedures around which actors' expectations converge in a given area of international relations"). Id. Patterned conduct that reflects on-going assessments (and re-assessments) of interest tend to give rise to regimes, that, in turn, reinforce patterned actions. Id. at 100-01. In a Grotian international order, regimes constitute a "significant and pervasive phenomenon" deserving of the sort of attention accorded to variables such as power. Id. at $97,101$.

193. Wendt, supra note 174 , at 87.

194. See id. 
the game are frozen in a black box and thereby considered "exogenous to interaction." 195

The accretive process, whereby egoists learn cooperative behavior, is simultaneously a "process of reconstructing their interests in terms of shared commitments to social norms."196 Thus, even if egoistic reasons are the starting point, the process of cooperation - in the absence of "negative identification" - incrementally recasts those original reasons by "reconstituting" and refocusing identities and interests in light of "new intersubjective understandings and commitments." 197

Although such transformation in interest conceptualization is largely unintended, there is always the prospect of "critical [strategic] self-reflection" marked by "self-conscious efforts" to dramatically alter the prevailing configurations of identity and interest. ${ }^{198}$ Despite the constraining social determinants of self, the "personal determination of choice," catalyzed by reasons for new thinking and unprecedented situations, could impel actors to change their identities and interests and thereby reinvent the game in which they are "embedded." 199 If other actors reward the new practices ushered in by new thinking, this reciprocity lays the foundation for a new process of socialization that leads to the re-conceptualization of identities and interests. ${ }^{200}$

As emergent cooperative patterns are transformed into a mature cooperative security system, states re-conceptualize basic realist variables, such as interest and security. In such cooperative systems, states "identify positively with one another" such that each state's security is viewed as a collective responsibility. ${ }^{201}$ In effect, the relevant "self" for purposes of interest conceptualization is "the community" and "national interests are

195. Id. at 86.

196. Id. at 87 .

197. Id. at 88 .

198. See id.

199. Wendt, supra note 174 , at 89 . Wendt cites the "New Thinking" of Mikhail Gorbachev as an instance and he lamented the fact such critical strategic theory and practice had received scant attention from the students of international politics. See id. Rather than taking extant institutions and social power relations as givens, critical theory "stands apart from the prevailing order of the world and asks how that order came about." See Cox, supra note 168 , at 346. Critical theory is geared towards an assessment of the:

very framework for action, or problematic, which problem-solving theory accepts as its parameters. Critical theory is directed to the social and political complex as a whole rather than to the separate parts ... the critical approach leads towards the construction of a larger picture of the whole of which the initially contemplated part is just one component, and seeks to understand the processes of change in which both parts and whole are involved.

Id. Whereas the problem-solving theories are favored in conditions of apparent stability, "a condition of uncertainty in power relations beckons to critical theory as people seek to understand the opportunities and risks of change." Id.

200. See Wendt, supra note 174 , at 90 .

201. Id. at 81 . 
international interests." ${ }^{202}$ Identification with the community varies from limited "concerts" to extensive collective security arrangements. ${ }^{203}$ The character or practices of the emergent "collective self" is in differing degrees "altruistic or prosocial" and consequently, states' efforts to advance their interests (power politics) are restructured "in terms of shared norms rather than relative power." ${ }^{204}$ Thus, being treated by others in "empathic" ways regarding security allows for the "positive identification with others necessary for collective security." ${ }^{205}$ Conversely, predatory and aberrantly aggressive egos or bad apples will contaminate the system, forcing other states to behave likewise. ${ }^{206}$

The mix of national interests is neither fixed nor exogenously ordained: in a dynamic international system, interests are progressively transformed or modified by new knowledge and patterns of sustained interactions. With respect to AIDS, the global focus on HIV/AIDS as a security threat was spurred, in part, by a decisive rethinking of U.S. national interests with regard to international health and a more comprehensive view of nexus between national and international security, broadly conceived. ${ }^{207}$ The conceptions of U.S. national interest and security (traditional realist variables) were transformed by new understanding about the catastrophic potential of the AIDS, new knowledge about the processes of bio-globalization and visionary reflectivity regarding these new trends. New thinking about security in the vortex of the pandemic ushered in a novel "consensus" 208 about imperative values intrinsic to the long term sustainability and governance of a nascent global society besieged by seemingly implacable microbial foes.

In effect, the new thinking on international security in the era of AIDS was arguably fueled by a "breakdown of consensus" ${ }^{209}$ about possibilities of statecentrism in the era of bio-globalization. Just as the collapse in consensus about the possibilities of Marxist-Leninism precipitated Gorbachev's perestroika, ${ }^{210}$ so too did the international community awaken to a new way of thinking about national and international interests in the era of globalization and a most ominous plague. Next, the article examines more closely the gradual transformation and re-conceptualization of U.S. national (security) interests with respect to AIDS in Africa and their integration into conceptions

202. Id.

203. See id.

204. Id.

205. Id. at 83.

206. See Wendt, supra note 174 , at 83.

207. See generally Emerging Infectious Diseases, supra note 77.

208. Wendt, supra note 174, at 89 . Wendt argues that a "breakdown in consensus" about commitments regarding the Soviet Leninist logic precipitated Gorbachev's abandonment the conflict-laden schematic. See id.

209. Id.

210. See id. Wendt attributes the demise of Marxism-Leninism to a breakdown in the old consensus regarding the viability of that ideology in a changed world. See id. 
of international interests - at least on the matter of responding to the global AIDS pandemic.

\section{Redefining Interests \& Priorities in a Changed World: The U.S. Case}

In the mid eighties, the Reagan and Bush administrations were in possession of highly classified intelligence reports about the potential scale and scope of the burgeoning AIDS pandemic. ${ }^{211}$ Yet there was a prevailing view among U.S. officials that AIDS in Africa and other developing countries was of very little concern to the United States. ${ }^{212}$ In other words, staving off the looming epidemic was not in the national interest, and hardly a subject for national security officials to devote significant attention. In fact, two CIA analysts, Katherine J. Hall and William L. Barrows, were rebuffed by the CIA when they sought agency backing to study the mushrooming pandemic. ${ }^{213}$ For a three year period (1987-1990), the CIA rejected requests for personnel and resources to study the epidemic, arguing that it was not an appropriate issue for intelligence agencies. ${ }^{214}$

By 1990, the CIA relented and it sanctioned an intelligence appraisal of the burgeoning epidemic. ${ }^{215}$ The resultant classified document titled "The Global AIDS Disaster" (Interagency Intelligence Memorandum 91-10005 of July 1991), predicted that AIDS will grow to catastrophic proportions with a projected 45 million infections by $2000 .^{216}$ At about the same time, a World Health Organization (WHO) report predicted that that tens of millions would be infected and would eventually die by $2000{ }^{217}$ The CIA's report on the global AIDS disaster as well as other reports predicting similar calamities were reportedly greeted with "indifference" and inaction by Bush administration officials. ${ }^{218}$

The indifferent or lackluster U.S. response to AIDS in the Reagan and Bush administrations was, in part, a function of the conventionally myopic approach to assessing national interest. This traditional conception of national interest was wedded to the notion of narrow strategic issues related to power and positioning, as shaped by the post Cold War era. It was also fueled by a

211. See generally Barton Gellman, Death Watch: The Belated Global Response to AIDS in Africa, available at http://washingtonpost.com/issues/aidsinafrica/A47234-2000Jull4.html (last visited July 14, 2000). The discussion here is a more comprehensive treatment of the national interest issue raised in one of my earlier articles. See Spectar, Hybrid Horseman, supra note 13 , at 256-73 (briefly alluding to the national interest issue).

212. Id.

213. See id.

214. See id.

215. See id.

216. See id.

217. See Spectar, Hybrid Horseman, supra note 13, at 256-73.

218. See id. 
sense that Africa was not an area that the United States needed to concern itself about, except perhaps for its Cold War-bound strategic interests in gaining access to certain resources and important straits or sea lanes. ${ }^{219}$ Further, there was such a degree of apathy in some circles that it prompted this writer to dub the African continent the poster child for man's indifference to man. ${ }^{220}$ As one U.S. official stated, the epidemic "will be good, because Africa is overpopulated anyway."221 The large populations and high unemployment rates meant African militaries could also draw from a "limitless [and fungible] pool of unemployed men" to replace AIDS fatalities. ${ }^{222}$ Others cynically observed that the deaths of senior African military officials from AIDS would improve morale as more junior officials would be buoyed by the possibility of promotions to higher ranks. ${ }^{223}$ In sum, the consensus among administration analysts was that even if the epidemic was going to be as large as predicted, combating AIDS was not in the U.S. national interest, and in any case, there was little the U.S. could do to prevent it. ${ }^{224}$

Following the arrival of the internationalist Clintonites in Washington, one could discern a shift in the rhetoric, tone and substance of U.S. foreign policy with regard to Africa and AIDS. ${ }^{225}$ There was a sense that President Clinton would be both more internationalist and more pro-Africa in his articulation of foreign policy goals. These expectations were, for the most part, fulfilled; although, several contradictions and blunders marred Clinton's

\section{See infra.}

220. See Comments by author, Human Rights Symposium, University of Connecticut, December 2001.

221. Gellman, supra note 211, at 3. See also Spectar, Hybrid Horseman, supra note 13 , at 256-73.

222. See Gellman, supra note 211 , at 3 . One U.S. official reportedly stated: "If you have one 18-year old with a Kalishnikov and he dies, you find another 18-year-old." Id.

223. Gellman, supra note 211 , at 3.

224. See id.

225. See Tom J, Farer, International Law: The Critics are Wrong, in FOREIGN POLICY 22 (1988). Tom Farer defines internationalism as an overall "foreign-policy orientation" marked by "international cooperation, international law and institutions, economic interdependence, international development, diligence in seeking arms control, and restraint in the use of force." Id. Intemationalist foreign policy-making is facilitated by the participation of governing elites (specialists and generalists), global citizens, and, members of epistemic communities who share some or all of the following traits: a critical understanding of how global and local (domestic) processes/problems interact; compassion, solidarity, empathy and goodwill towards all human beings qua human beings; a favorable disposition towards constructive cooperative and multilateral approaches to global governance; respect for international human rights; support for international law; and, a willingness to challenge, exhort, and, lead, the domestic populace to look beyond borders, and to seek the greater good and long term happiness of all humankind - even at some marginally higher short term cost. See id. U.S. foreign policy sometimes alternates or oscillates between variants of internationalism and feckless flirtations with isolationism, depending upon the quality of extant presidential leadership and the attendant coterie of foreign policy courtiers. See id. Elsewhere, I have discussed presidential election cycles and their impact on the internationalist quality of legal positions staked out by the United States in negotiations over the global commons. See generally J.M. Spectar, supra note 158. 
Africa record. ${ }^{226}$ For purposes of this article, it sufficeth to say that the new administration was more responsive to the intelligence estimates about the impact of AIDS, and it took steps to raise the profile of the pandemic in U.S national interest articulation and formulation.

The Clinton-Gore administration effectively presided over a dramatic redefinition of U.S. national interests in light of the new age of bioglobalization and ancillary governance dilemmas. The administration's redefinition of national interest with respect to the pandemic was partly fueled by "new" facts and findings about the interconnectedness of global processes, a greater appreciation of the challenges of global governance, as well as by the determined efforts ardent spokespersons with a deep concern for Africa. In effect, a paradigmatic re-interpretation of U.S. interests and obligations was increasingly evident throughout the Clinton Administration-a shift marked by a growing focus on a range of issues hitherto confined to the under valued realm of "low politics." This transformation eventually culminated in U.S. leadership on the passage of the Security Council Resolution on HIV/AIDS and the emergence of a new global consensus on security.

Clinton administration officials were spurred to action not just by data showing the extent of the pandemic, but by a growing understanding of the increasingly interconnected nature of the threats confronting the United States. In particular, U.S. policy makers were making new interconnections between the escalating threats posed by major infectious diseases (AIDS, tuberculosis, malaria, cholera, and hepatitis) and a range of other U.S. interests in the age of globalization. The growing recognition and articulation of these interconnections increasingly shaped the development of U.S. foreign policy goals by senior officials. The public perorations of U.S. officials about the interconnections between infectious diseases, communications technology, mass migrations, and security in a closely connected globalizing planet provided evidence of critically reflective and "self-conscious efforts"227 to significantly change the prioritization of key U.S. interests.

A close examination of the Clinton Administration foreign policy, especially from 1995-2000, reveals a marked shift in articulation of U.S. foreign policy goals - at least on the priority accorded issues of global health. The Clinton administration intentionally changed U.S. rhetoric, as well as diplomatic posturing on AIDS, paving the way for a surge of internationalist activism on a global scale. Partly due to strong presidential leadership, the

226. While a general analysis of Clinton's Africa policies is well beyond the scope of this article, some of the more glaring failures and missed opportunities included the Somalia debacle as well as the Clinton's administration's inability/unwillingness to help contain the massacre in Rwanda. (Arguably, the administration became gun-shy after the Somalia morass and retreated from further military engagement in Africa's unceasing military quagmires). In addition, the administration's initial backing of pharmaceutical companies on the matter of compulsory licensing of AIDS therapies as well its ill-timed and ill-fated bombing of a Sudanese factory left many observers befuddled.

227. Wendt, supra note 174 , at 88 . 
new conceptions of national interest, national security, and world interest were increasingly integrated into U.S. foreign policy pronouncements and positions. In addition, the Clinton administration provided commendable international leadership ${ }^{228}$ as it worked ensure the global diplomatic agenda included efforts to combat the global AIDS pandemic.

By the mid-nineties, the Clinton administration was confronted with data about the scope and potential ramifications of the AIDS virus and other microbial threats. ${ }^{229}$ The administration was quickly spurred into developing a global effort to fight infectious diseases because it recognized the futility of unilateral efforts in an era of accelerating bio-globalization. It was apparent that the staggering costs of controlling the coming microbial threats far outstripped "the means available to any one country or international organization to respond completely, ${ }^{, 230}$ In addition, a 1995 report by the National Science and Technology Council's Committee on International Science, Engineering and Technology (CISET) revealed that the annual aggregate cost to the United States for infectious diseases exceeded an estimated $\$ 120$ billion. ${ }^{231}$

The Clinton Administration was also impelled to critically rethink national interest and security because of the confluence of related events, including the extant revolution in communications technologies (that made the world even smaller), as well as the quickening processes of globalization. Due to rapid technological growth and the increasing mobility of populations, threats that were once perceived as local could now have catastrophic consequences on a regional or global scale. ${ }^{232}$ As the pace of bio-globalization quickened, U.S. leaders recognized they had to adjust their conception of international security to reflect a new world of increasingly menacing globetrotting viruses. Wendy Sherman, a diplomat in the Clinton administration stated:

228. See id. The Clinton Administration's Africa record was occasionally marred by some notable failures and squandered opportunities. As Ambassador Sherman stated, U.S. "responses to these challenges must engage the foreign affairs and national security community along with the health community here and abroad." Emerging Infectious Diseases, supra note 77.

229. Reasons for the resurgence and proliferation of microbial threats include: " $[\mathrm{g}]$ rowing global population, changes in climate, massive demographic shifts, poverty, greater population mobility and other imbalances between people and nature .... Industrialization and even health technologies such as antibiotics have had unintended consequences, including the development of antibiotic resistance." Id. (Remarks by former Ambassador Wendy Sherman).

230. Id. (Bureau of Oceans and International Environmental and Scientific Affairs). For its part, the U.S. State Department set up an Emerging Infectious Diseases and HIV/AIDS Program (EID) under the auspices of the Bureau of Oceans and International Environmental and Scientific Affairs. See id. The EID Program is the nerve center for the development and implementation of U.S. foreign policy objectives with regard to the resurgence of microbial threats and HIV/AIDS. Id. The EID Program represented the State Department to departments in the U.S. government as well as to foreign governments and international organizations. See id.

231. See id.

232. See Emerging Infectious Diseases, supra note 77. 
Infectious microbes do not recognize international borders. The modern world is a very small place where any city in the world is only a plane ride away from any other. Infectious microbes can easily travel across borders with their human or animal hosts, in the food and products we trade. No nation is impervious to these health threats. Beyond the terrible AIDS pandemic and the more exotic, publicized diseases such as the Ebola virus in the former Zaire, lie a wide range of microbiological threats. ${ }^{233}$

Noting that these diseases are "the silent enemies of economic growth, national well-being and stability around the globe," Sherman observed that "the threats they pose and the devastation they portend give reason to reexamine how we define "national security." 234

By the end of the nineties, the Clinton Administration was effectively treating emerging infectious diseases as growing global health threat capable of imperiling several U.S. national interests. The administration believed U.S. national interests were affected because infectious diseases are a challenge to health and economic productivity, ${ }^{235}$ as well as a danger to economic development and political stability abroad. ${ }^{236}$ In addition, there are "potential dangers of bio-terrorism," 237 as well as the "necessity of enhanced preparedness to safeguard the U.S. and the global community against the threat of infectious diseases." ${ }^{238}$ Furthermore, the U.S. faces the challenge of mobilizing technical and financial resources "to reduce human suffering and stem further disease transmission." ${ }^{239}$ Additionally, intelligence reports began to indicate that AIDS and other ravaging epidemics will eventually be significant triggers of conflicts in the Third World, and, in some cases, determine the results of conflicts in the near future. ${ }^{240}$ Also, the potential of destabilizing mass migrations spurred by disease and conflict was a source of concern to some analysts. ${ }^{241}$ For these reasons, the Clinton Administration gradually expanded its notions of national security to embrace the fight against

233. See id.

234. Id.

235. See id. (Bureau of Oceans and International Environmental and Scientific Affairs).

236. See id.

237. Id.

238. Emerging Infectious Diseases, supra note 77.

239. INTERNATIONAL RESPONSE, supra note 61.

240. See, e.g., Chalk \& Brower, supra note 44.

241. See, e.g., Alan Dowty \& Gil Loescher, Refugee Flows as Grounds for Intermational Action, INTERNATIONAL SECURITY. Policy makers have not shown sufficient appreciation for the destabilizing potential of extant and future mass migrations fueled by disease, resourcediminution, famine, war and poverty. See id. As this writer warned in an earlier piece, U.S. presidents in the new millennium must be prepared to contend with inter alia, "mass migrations" from failed states. See Spectar, supra note 158, at 1037-38. 
AIDS - a pandemic it described as "one of the most significant health and security challenges facing the global community."242

Consequently, in 1999, the U.S. called on governments around the world to "recognize the political and economic security implications of the pandemic" and to support a vigorous and sustained response to the disease as a major national and international priority. ${ }^{243}$ To illustrate this new commitment, the USG sought to "broaden" its approach to infectious disease issues and to include AIDS related issues at the heart of discussions with national leaders at the highest levels. ${ }^{244}$ In sum, the increasing awareness of the changes wrought by bio-globalization and associated processes compelled a reassessment of priorities-if only because of the harrowing scenarios conjured by inaction. As Samuel Berger, national security adviser to former president Clinton stated:

We understand, I think, ... [in a] global age, and a global economy that instability in other parts of the world which can lead to war and conflict can have a direct effect on the United States. And I think we have an obligation to act with others to try to both deal with the consequences and increase the degree of education and prevention to try to slow this down. ${ }^{245}$

Besides the policy-oriented reasons for the reformulation of U.S. interests, the "self-conscious" reflectivity and zealous advocacy of key U.S. spokespersons catalyzed the process of rethinking and reassessment. The most ardent articulator of Clinton Administration policy on the global pandemic was Richard Holbrooke, a former UN Ambassador. It can be argued that Holbrooke, with some assistance from Vice President Gore, was the pivotal actor in the redefinition of U.S. national interests in this area. For Ambassador Holbrooke, the battle against AIDS was clearly the premier issue of the global agenda:

Of all the problems that we face in the world today and there are many-the conflicts we are here to try to prevent or

242. Emerging Infectious Diseases, supra note 77 (Bureau of Oceans and International Environmental and Scientific Affairs).

243. U.S. Department of State, U.S. Intermational Response to HIV AIDS, Office of the Spokesman Press Statement, (Mar. 16, 1999), available at http://secretary.state.gov/www/ briefings/statements/1999/ps990316.html (last visited Jan. 13, 2003). As Ambassador Sherman stated, the U.S. has "practical as well as humanitarian reasons for broader international action against infectious diseases." Emerging Infectious Diseases, supra note 77, at 2.

244. Id.

245. See Online Newshour, National Security Threat, available at http://www.pbs.org/newshour/bb/health/jan-june00/aids_threat_5-2.html (last visited Mar. 3, 2003). 
contain; nuclear proliferation, population issues, environmental issues, and social and economic issues--I think that [AIDS] is the most serious problem we face because of the damage that it can do to everything else. ${ }^{246}$

As Richard Holbrooke argued, it is in the interest of states to "broaden the paradigm of security" by focusing on issues such as AIDS and refugees. ${ }^{247}$ Holbrooke challenged policy makers to reassess their view of ADS as just another health issue. Such thinking was imperative to grapple with the "the greatest global pandemic of our time," which had quickly morphed into diplomatic, economic, trade, security and human rights issue. ${ }^{248}$ Holbrooke maintained the global scope of the pandemic necessitated concerted international action:

AIDS is not just the problem of a single country. It is not just an African problem. It cannot be treated simply as a problem of a single continent. In a world defined by globalization and interdependence - two of the catchwords of the modern era-we can't do triage by countries or continents. And we can't simply focus on economic interdependence. We have to recognize that while interdependence gives economic opportunities, it also can pose global threats. You cannot deny AIDS a visa; you cannot embargo it or quarantine it; you cannot stop it at a border. That's why we must work together. ${ }^{249}$

Besides redefining its own strategic priorities to include the war against HIV/AIDS, the U.S. urged other nations to make AIDS a priority. President Clinton placed infectious disease in his agenda during both of his African trips, ${ }^{250}$ where promised assistance to fight AIDS and challenged Africans to take responsibility. In addition, President Clinton subsequently included AIDS in his agenda for all regions, including the Economic Summit with the major industrialized nations (G-8) at Okinawa. ${ }^{251}$ Similarly, during her 1999 visits to

246. Remarks Following Vote, supra note 78.

247. Statement During the Open Meeting on the Month of Africa, New York, Jan. 31, 2000, available at http://www.state.gov/www/policy_remarks/2000/000131_holbrooke_africa.html (last visited July 19, 2000) (Statement by Ambassador Holbrooke).

248. Statement for the Record, supra note 96.

249. Remarks Following Vote, supra note 78.

250. See Emerging Infectious Diseases, supra note 77. See also Clinton Embarks on Trip to Nigeria's Struggling Democracy, available at http://www.cnn.com/2000/WORLD/africa/ 08/25/clinton.africa/index.html (last visited Aug. 25, 2000). In that visit, President Clinton offered Nigeria additional financial support in its struggle against infectious disease. See id. at 2.

251. See Emerging Infectious Diseases, supra note 77. 
Mali, Guinea, Sierra Leone, Nigeria, Kenya, and Tanzania, Secretary of State Albright included HIV/AIDS in her discussions with African Heads of State. ${ }^{252}$ In addition, U.S. Ambassador Holbrooke's diplomatic missions to Africa placed the AIDS crisis, along with the related issue of conflict at the top of the agenda. ${ }^{253}$

Nevertheless, given the politicized context of these determinations and policy initiatives, there was considerable dissension about this national interest re-prioritization, especially among certain republican ranks. For example, in the United States, Senate Majority Leader Trent Lott stated that he did not consider AIDS to be a threat to national security and he accused the White House of playing politics with the issue. ${ }^{254}$ In addition, while testifying before the Senate Relations Committee, Holbrooke disclosed that the U.S. "idea" to hold a special Security Council session on AIDS was "initially met with some resistance, including from inside the U.S. Mission." 255

The dissenting views notwithstanding, U.S. leadership on this issue was clearly causing the rest of the world to fall in line. Partly as a result of U.S leadership, the pandemic was one of the main issues in the global diplomatic agenda in between $1999-2001,{ }^{256}$ as evidenced by proclamations in major international conferences in from Durban to Okinawa. ${ }^{257}$ In what was arguably most visible sign in the on-going redefinition of U.S. national interest ordering the Security Council with very strong U.S. nudging took up a health-only matter for the first time in summer $2000 .^{258}$

252. See, e.8., Remarks by U.S. Secretary of State Madeleine K. Albright, HIV/AIDS Event, Kibera District Office, Nairobi, Oct. 22, 1999, available at http://secretary.state.gov/www/ statements/1999/991022.html (last visited Apr. 21, 2000).

253. See Statement for the Record, supra note 96.

254. See Clinton Administration Declares AIDS a Security Threat, available at http://www.cnn.com/2000/HEALTH/AIDS/04/30/aids threat.03/index.html (last visited Aug. 25,2000 ). Lott charged: "This is just the president trying to make an appeal to certain groups." Id.

255. Testimony Before the Senate Foreign Relations Committee, Washington DC, July 12 , 2000, available at http://www.state.gov/www/policy_remarks/2000/000712_holbrooke_ africa.html (last visited July 26, 2000) (testimony of Richard Holbrooke).

256. The horrendous terrorist attacks of September 11 th also changed the global issueordering, moving AIDS and other social issues from the forefront of the international diplomatic agenda.

257. In light of the mutually reinforcing link between AIDS and conflict, the conferees at Okinawa urged the international community to act urgently and effectively to prevent and resolve armed conflict and to foster a "Culture of Prevention" worldwide. See G-8 Okinawa, available at http://usinfo.state.gov/topical/econ/group8/ summit00/g8forini.htm (last visited Mar. 3, 2003).

258. See First Health-Only Resolution, supra note 69. 


\section{The Security Council's First Health-Only Resolution \& Its Impact}

In a clear demonstration of its revised issue-prioritization, the U.S. strongly supported and even championed Security Council involvement in the AIDS crisis. At the 4086th Security Council Meeting on January 10, 2000, the United States challenged the international community to rethink the pandemic as a security issue. The United States urged the Security Council to "work toward a resolution that describes and responds to the impact of AIDS as a cause and consequence of security crises." ${ }^{259}$ In particular, the United States urged the Council to do more to "address the tragic relationship between AIDS, conflict, and peacekeeping." 260

The new focus on AIDS in the Security Council was in large measure the product of the joint efforts of Richard Holbrooke and Albert Gore, both of whom were determined to approach the matter multilaterally within the framework of the UN system. ${ }^{261}$ Given their shared preference for concerted and coordinated multilateral action, the duo was able to lead the Council through uncharted waters as the debate proceeded on this unprecedented resolution. With Holbrooke and Gore leading the charge and declaring AIDS a threat to international security, other states took their cue from robust U.S. leadership, thus precipitating a series of similar proclamations. ${ }^{262}$ As $\mathrm{Mr}$. Gore stated, AIDS is a security issue because it "strikes at the military, and subverts the forces of order and peacekeeping." ${ }^{263}$ In his groundbreaking peroration at the Security Council meeting on AIDS, Mr. Gore implored the international community to "wage and win a great and peaceful war of our time -- the war against AIDS.",264

The unanimous resolution of July 18,2000 sought to intensify the war against AIDS by calling on countries to design and implement long-term strategies to stave off the pandemic. ${ }^{265}$ The resolution noted that the Security Council was "deeply concerned by the extent of the HIV/AIDS pandemic worldwide, and by the severity of the crisis in Africa in particular."

259. See Statement for the Record, supra note 96.

260. See id.

261. It was also happened to be very convenient for the two men that the resolution came up at a time when the U.S. had the presidency of the Council and therefore had a little more leverage in setting or moving the agenda forward.

262. Remarks as Prepared for Delivery by Vice President Al Gore, supra note 54.

263. See id.

264. See id.

265. See UNAIDS Executive Director Addresses Security Council, Commends Draft Resolution on HIVIAIDS, available at http://www.unaids.org/whatsnew/press/eng/newyork 170700.html (last visited Aug. 11, 2000).

266. Security Council Resolution 1308, Relating to HIV/AIDS, Adopted by the Security Council at its 4172nd Meeting July 17, 2000, United Nations Security Council, available at http://www.state.gov/www/regions/africa/ 000717_unsc_hivaids.html (last visited Aug. 5, 2000). 
preamble, ${ }^{267}$ the Security Council recognized that "the spread of HIV/AIDS can have a uniquely devastating impact on all levels of society" and it reaffirmed "the importance of a coordinated international response to the HIV/AIDS pandemic, given its possible growing impact on social stability and emergency situations." ${ }^{268}$ In particular reference to the emerging linkage between the pandemic and conflict and global instability, the Security Council stated:

The HIV/AIDS pandemic is also exacerbated by the conditions of violence and instability, which increase the risk of exposure to the disease through large movements of people, widespread uncertainty over conditions, and reduced access to medical care, [and] the HIV/AIDS pandemic, unchecked, may pose a risk to stability and security. ${ }^{269}$

The resolution specifically singled out armed forces and peacekeepers, expressing the Security Council's "concern at the potential damaging impact" of AIDS on the health of international peacekeepers and their support personnel. ${ }^{270}$ The Council

Encourages all interested Member States which have not already done so to consider developing, in cooperation with the international community and UNAIDS, where appropriate, effective long-term strategies for HIV/AIDS education, prevention, voluntary and confidential testing and counseling, and treatment of their personnel, as an important part of their preparation for peacekeeping operations .... [and] (4) Encourages Member States to increase international cooperation among their relevant national bodies to assist with the creation and execution of policies for HIV/AIDS prevention, voluntary and confidential testing, and treatment for personnel to be deployed in international peacekeeping operations. $^{271}$

267. Sometimes the debate focused on seemingly trivial matters. As the discussion unfolded, the Members of the Security Council even wondered whether they "could put preambular language into a resolution." Holbrooke Remarks Following Sec. Council Vote, supra note 78.

268. Security Council Resolution 1308, Relating to HIV/AIDS, supra note 266.

269. Id.

270. See id.

271. Id. The resolution also requests the Secretary General to "take further steps" to accomplish the objectives of protecting peacekeepers from AIDS. Id. at $\S 3$. Furthermore, the resolution encourages UNAIDS "to further develop its country profiles in order to reflect best practices and countries' policies" on AIDS. Id. \&5. 
Amazingly, this unprecedented resolution was passed unanimously, even though it dealt with a subject hitherto considered unsuitable for diplomacy or 'high politics.' In addition, the proponents were able to overcome the resistance of those who viewed this resolution as an unwarranted and unauthorized interference in the domestic jurisdiction of UN Member States.

Supporters of the resolution viewed its passage as a clarion call in the battle against AIDS; they rejected the imputation that it was merely a symbolic gesture presented with plenty of pomp and protocol. The resolution was clearly "historic for the Security Council" and it constituted an "important benchmark in the process" of fighting against AIDS. ${ }^{272}$ Additionally, supporters argued the measures in the resolution were "significant steps" 273 and even "ground-breaking."274 As a delegate to the Security Council stated, the importance of the debate "lies in raising awareness" of the devastation and of the "greater threat ahead if effective action is not taken." 75

Furthermore, supporters hoped that resolution would "go a long way towards ending"276 the link between AIDS and peacekeeping, especially to the extent that humanitarian aid workers, military personnel properly trained in HIV prevention and behavioral change could serve as force for prevention. ${ }^{277}$ For his part, Richard Holbrooke sought U.S. congressional support for implementation of the resolution, particularly with respect to the education of peacekeepers about the dangers of AIDS. ${ }^{278}$ As if to accentuate the new consensus about U.S. perception of its interests, Holbrooke vowed before Congress that "the U.S. will never again vote for a peacekeeping resolution that does not require specific action by the UNDPKO to prevent AIDS from spreading by or to peacekeepers." 279

However, some were miffed by what they saw as the resolution's excessively narrow focus and the missed opportunities with respect to dealing with the wider issues relating to treatment equity and poverty-as-a-pandemicpurveyor. Despite the broad support for the U.S.-backed approach, some wondered whether the U.S. had defined the issue too narrowly, addressing only U.S. interests while deftly ignoring the larger issues. They criticized its narrow focus on AIDS among peacekeepers rather than on the urgent matter

272. Remarks Following Vote, supra note 78.

273. Id.

274. Id.

275. Press Release, Debate on Impact of AIDS, supra note 58, at 14.

276. Remarks Following Vote, supra note 78.

277. See UNAIDS Executive Director Addresses Security Council, supra note 266. While Mr. Holbrooke must be commended for his exemplary savoir faire, the savvy plenipotentiary was also willing to share credit with others, especially Dr. Piot of UNAIDS. See id. Speaking of Piot, Holbrooke noted that "[W]ithout his vision, his creativity, and his leadership, I don't think we would be here today, and I know that he has told me privately how important the Security Council's efforts are in his efforts." Remarks Following Vote, supra note 78.

278. See Statement for the Record, supra note 96.

279. Id. 
of treatment equity. ${ }^{280}$ While the resolution "expresses keen interest" in further discussions about access to treatment and care, ${ }^{281}$ it did not go as far as many in the South had hoped. The delegate from Zimbabwe expressed his disappointment with this limited approach stating, "It remains painfully clear that the profit motive takes precedence over humanity's well-being."282

While some saw the focus on peacekeeping as limiting, Holbrooke took the view that the resolution was an important and targeted step that focused on a key aspect of the problem. Even as he acknowledged that the resolution primarily focused on peacekeeping, Holbrooke maintained that "the ultimate goal must be to increase international intensity and coordination against HIV/AIDS across the board." ${ }^{283}$

\section{B. Sovereignty}

The new global understanding of AIDS as a security threat and the global response thereto warrants a rethinking of the principle of sovereignty, particularly as it relates to the putative exclusivity of UN Member states' dominion over so-called "matters essentially within the [member states'] domestic jurisdiction." ${ }^{284}$ The principal argument is that due to the extant and emerging threats in the age of bio-globalization, the archaic and static realist conceptions of sovereignty must be modified or discarded in favor of dynamic institutionalist approaches that connect the domestic and international planes in a seamless framework of universal human rights and responsibilities. Below, the article explores the nature of sovereignty and the necessity of a reconceptualization in the age of globalization, particularly in light of the UN resolution on AIDS.

At the dawn of the seventeenth century and prior to the emergence of the nation-state as we know it, Jean Bodin set forth a doctrine of sovereignty in which the monarch was an absolute ruler within his/her dominions, but equal externally with respect to other sovereigns. ${ }^{285}$ Only by voluntary agreement could the sovereign monarch incur obligation from abroad. ${ }^{286}$ Following the emergence of the territorial state and the creation of the state system, the

280. See First Health-Only Resolution, supra note 69.

Given the dearth of access to AIDS therapies in the South, many in developing countries argued that the focus should be on achieving treatment equity by increasing access to affordable therapies by price reductions, subsidies and even compulsory licensing. See id. For more on the treatment gap as well as recommendations to narrow the gap, see Patent Necessity, supra note 13 .

281. Security Council Resolution 1308, Relating to HIV/AIDS, supra note 266.

282. First Health-Only Resolution, supra note 69.

283. Remarks Following Vote, supra note 78.

284. U.N. CHARTER, supra note 4

285. See HumAN RightS IN THE WORLD COMMUNITY 4 (Richard Pierre Claude \& Burns H. Weston eds., 1989); James E. Dougherty \& Robert L. Pfaltzgraff, Contending THEORIES OF INTERNATIONAL RELATIONS 8 (1971).

286. HUMAN RIGHTS IN THE WORLD COMMUNITY, supra note 285, at 4. 
virtually absolutist notions of sovereignty postulated by Bodin became "the most important notion for both domestic and international politics."287 Consequently, Stanley Hoffman referred to sovereignty as "the prevalent structure of the international system," and he summed up the last two and half or three centuries of international relations as "the age of sovereignty." 288 Similarly, Falk acknowledges that the predominant world ordering logic ${ }^{289}$ since Westphalia has been the statist framework of Bodin and subsequently Emmerich de Vattel. ${ }^{290}$

Many commentators continue to wrestle with the "bothersome concept" ${ }^{" 291}$ of sovereignty, bemoaning the lack of consensus regarding its implications for world order and justice. ${ }^{292}$ According to Kenneth Waltz, the concept of sovereignty suggests that each state "unit" is like every other in so far as each state is "an autonomous political unit."293 The sovereign state determines on its own accord, the strategies necessary for coping with its internal and external problems, including whether seek outside assistance and, in doing so, to voluntarily constrain its freedom by making commitments or concessions to other states. ${ }^{294}$ As Falk observes, the statist logic, associated with the "will of the territorial sovereign state" has resulted in the government of the state acting as the de jure exclusive agent with regard to formulating the will of the state in external relations. ${ }^{295}$ On the domestic front, the principle of sovereignty "signified the establishment of hierarchical patterns of authority"; at the international level, sovereignty symbolized the putative "equality of autonomous actors, analogous to the status of property holders in Roman private law." 296 At the core of the principle is the notion that the state "is

287. KRATOCHWIL \& MANSFIELD, supra note 168 , at xi.

288. STANLEY HOFFMAN, DUTIES BEYOND BORDERS 46 (1981)

289. See Richard Falk, Theoretical Foundations of Human Rights, in HUMAN RIGHTS IN THE WORLD COMMUNITY, supra note 285, at 30. Richard Falk has identified "competing normative logics" that arguably provide "independent basis for structuring behavior in prescribed directions." Id. A normative logic constitutes "a set of propositions about what ought to happen with respect to the exercise of authority in the world political system." Id.

290. See id. at 30.

291. WALTZ, supra note 173 , at 95.

292. See StOETT, supra note 2, at 6 . Peter Stoett hints at the confusion when he poses a series of tantalizing questions relating to the obfuscating nature of the term:

Does it imply territorial integrity, and autonomy from outside influence? Is it primarily a legal concept denoting the ultimate source of political authority in a given jurisdiction? Does it lay with the people, or citizenry? Or is it a term employed by ruling classes to hegemonize, or legitimize, unjust power relations? ... Is [sovereignty] diminished in some quantitative or qualitative sense as the state plays a less obvious role in the global economy?

Id.

293. WALTZ, supra note 173 , at 95.

294. See id. at 96.

295. See Falk, supra note 289, at 30.

296. KRATOCHWIL \& MANSFIELD, supra note 168 , at xi (citing John G. Ruggie, Continuity and Transformation: Toward a Neo-Realist Synthesis, 35 WORLD POLITICS 261-85 (Jan. 1983). 
subject to no other state and has full and exclusive powers within its jurisdiction without prejudice to the limits set by applicable law."297

Extreme expressions of sovereignty and non-interventionism alarm cosmopolitan thinkers. In its radical form, the institution of sovereignty "serves to perpetuate modern nation-states" to the detriment of social justice and human rights. ${ }^{298}$ For example, commentators who adopt a maximalist view of genocide see the nation state, and the system that supports it, as an accomplice in the deaths of millions either deliberately or unwittingly. ${ }^{299}$ It is argued that under the guise of sovereignty, states commit or encourage the commission of large scale atrocities, or permit the exacerbation of catastrophes such as the AIDS pandemic. ${ }^{300}$ Thus, Peter Stoett concludes, the "reluctance of some Asian and African governments to respond to the health needs of AIDS patients could be viewed as genocidal." ${ }^{301}$ Similarly, Stoett argues the eleven million children who die each year from easily preventable diseases can be considered victims of "silent genocide," 302 or what Henry Shue dubbed the "Holocaust of Neglect.",303 In the same vein, Leo Kuper remarked: "[T]he sovereign state claims, as an integral part of its sovereignty, the right to commit genocide . . . and the United Nations, for all practical purposes, defends this right." 304

Thus, when used as a shield, sovereignty is perceived as a threat to enforcement of international human rights and the creation of a just and sustainable world order. Consequently, it is no surprise that some maintain sovereignty is "an oppressive institution that aids the wealthy" and/or "precludes genuine international harmony." ${ }^{305}$ Exploiting the legal protections putatively afforded sovereignty, certain ruling elites effectively enjoy sanctuary or immunity from external intervention even as they foment or facilitate massive human rights abuses. ${ }^{306}$ In fact, gross human rights abusing states "typically" hide behind sovereignty and nonintervention as they demand all outsiders refrain from direct or indirect interference with their so-called

297. See Robert Keohane, International Institutions: Two Approaches, in KRATOCHWIL $\&$ MANSFIELD, supra note 168 , at 49 (citing the Wimbledon Case, Permanent Court of International Justice, series A, no. 1 (1923)).

298. STOETT, supra note 2 , at $42-43$.

299. See id. at 38-39.

300. See id. at 32.

301. Id. at 39.

302. Id. The term "silent genocide" was coined by Hiroshi Nakajima, director general of the World health Organization in regard to a WHO report that revealed about eleven million children die annually from simple diseases such as measles, pneumonia and diarrhea. Id. While Stoett points out the North and the affluent are complicit in these deaths, he concedes that "to charge them with outright genocide raises several unanswerable questions." Id. at 41.

303. HENRY SHUE, BASIC RIGHTS: SUBSISTENCE, AFFLUENCE, AND U.S. FOREIGN POLICY (quoted in STOETT, supra note 2, at 39).

304. LEO KUPER, GENOCIDE 161 (1982) (quoted in STOETT, supra note 2, at 39-40).

305. STOETT, supra note 2, at 42.

306. See id. 
"internal" affairs. ${ }^{307}$ In the seminal work, This Endangered Planet, Richard Falk claimed:

A world of sovereign states is unable to cope with endangered-planet problems...Such a system exhibits only a modest capacity for international cooperation and coordination. The distribution of power and authority, as well as the organization of human effort, is overwhelmingly guided by the selfish drives of nations. ${ }^{308}$

Sovereignty's doppelganger, the principle of non-intervention in the internal affairs of sovereign states, taken to its logical and perverse extreme poses a clear and implacable threat to the promotion of international human rights. The values imputed to sovereignty "a legal license to do your own thing" and its associated principle nonintervention ("an injunction to mind your own business") do not meld well with human rights concerns that require each to be her sister's keeper. ${ }^{309}$

Nonetheless, some argue that moderate expressions of sovereignty constitute a positive good for a system of states with unequal capabilities. As Wendt argues, the sovereign state depends on certain "intersubjective understandings and expectations" - leading to a particular type of community marked by a "mutual recognition of one another's right to exercise exclusive political authority within territorial limits."310 Sovereignty norms are "presupposed by an ongoing artifact of practice"; states thus act against the background of and thus replicate "shared norms" about understandings of the meaning of sovereignty. ${ }^{311}$ Therefore, the argument goes, to the degree that states "successfully internalize sovereignty norms they will be more respectful toward the territorial rights of others." 312 In this regard, David Strang argues that sovereignty has a constraining institutional effect to the degree that it increases the protection weak states [Vanuatu, Bahamas etc.] receive inside as opposed to outside "communities of recognition." 313

As states grapple with new emerging threats that defy borders, such the AIDS pandemic and other problems in the age of galloping globalization, the

307. See HUMAN RIGHTS IN THE WORLD COMMUNITY, supra note 285 , at 3.

308. RICHARD FALK, THIS ENDANGERED PLANET: PROSPECTS AND PROPOSALS FOR HUMAN SURVIVAL 37-38 (1971) (quoted in STOETT, supra note 2, at 21).

309. See HUMAN RIGHTS IN THE WORLD COMMUNITY, supra note 285, at 3.

310. Wendt, supra note 174, at 85.

311. Id.

312. Id. at 86 .

313. Id. at 86-87. Unlike the great power with significant national means, smaller powers with adequate capabilities may be more inclined to "learn faster that collection recognition is a cornerstone of security." Id. 
traditional realist conception of sovereignty is severely wanting. ${ }^{314}$ Conventional realists consider sovereignty the "defining feature" of the international political system ${ }^{315}$ and they effectively ascribe timeless features to sovereignty as a seminal, causal and analytical variable. At the same time, the power of the sovereign to determine, and act, according to national interests is accorded maximal deference, even when such actions contravene international legality. Realists often overplay the significance of sovereignty and perhaps as a result, overstate distinctions between hierarchy in the domestic setting marked by formal government, law, order and organized force and the international setting ostensibly marked by anarchy or the absence of hierarchy, norms and common values. ${ }^{316}$

Nonetheless, it is wrong-headed to equate the sovereignty of states with their ability to act arbitrarily or according to their wills and wishes. ${ }^{317}$ International cooperation is, or should be, possible because in spite of sovereignty, the system is not boundlessly anarchic. Even Bodin recognized the sovereign's power was not unlimited, because God, natural law, and, the law of nations bound the prince. ${ }^{318}$ While sovereignty may frustrate the creation of a hegemonic central authority, it does not preclude significant levels of international coordination and cooperation common problems. Sovereign states are sometimes "constrained" to act or not act in certain ways; they may be sovereign yet dependent on others and, of course, they may be impacted by the conduct of other sovereign actors. ${ }^{319}$ There is substantial cooperation in international politics; states conclude alliances or treaties, exploit common resources and assign exclusive property rights despite the lack of a world government. ${ }^{320}$ Additionally, states surrender certain rights to federations or supranational institutions and sometimes bear significant costs and hardship "to vindicate particular fundamental principles of international conduct." ${ }^{321}$ Further, sovereignty, like other basic realist/neorealist variables such as anarchy, security, rationality and power can be modified ${ }^{322}$ by social

314. See STOETT, supra note 2, at 21 (citing David Newman, The New Diplomatic Agenda: Are Governments Ready? INTERNATIONAL AFFAIRS 65:1, 29-42; 35 (1989)).

315. STOETT, supra note 2 , at 42 . According to the realists, while sovereignty is the defining feature, "international justice is thus contingent on an order based on sovereignty." $I d$.

316. See Edward Mansfield, The Organization of International Relations, in KRATOCHWIL \& MANSFIELD, supra note 168 , at 1 .

317. See WALTZ, supra note 173 , at $95-96$.

318. See DOUGHERTY \& PFAltZGrafF, supra note 285, at 8. With respect to the law of nations, the prince was bound by principles of customary international law (ius gentium) and by the principle that treaty obligations must be adhered to (pacta sunt servanda). See id.

319. See WALTZ, supra note 173 , at 96.

320. See Mansfield, supra note 316, at 2.

321. Id.

322. See Yosef Lapid, Theorizing the "National" in International Relations Theory: Reflections on Nationalism and Neorealism, in KRATOCHWIL \& MANSFIELD, supra note 168, at 29. 
reflection, learning and changes taking place in consciousness. ${ }^{323}$ Thus, even as sovereignty appears to be a permanent fixture on the international scene, the notion of untrammeled sovereignty is a canard.

To cope with the emerging threats of the 21 st century, it will be necessary to challenge the realists' static conception of sovereignty, and ipso facto, to embrace a dynamic institutionalist perspective. Liberal institutionalists view sovereignty as a "diffuse concept" that is intrinsically "part of a larger network of interstate communication and regime formation." ${ }^{324}$ The liberal institutionalist approach accounts for an evolutionary notion sovereignty and provides a viable framework for thinking about sovereignty and justice. Even as the territorial sovereign state "keeps proliferating," ${ }^{, 325}$ the nature and quality of coeval sovereignty is not static and the institution appears to be undergoing significant transformations.

Although the institution of sovereignty remained relatively unchanged in the first three centuries of the post Westphalia system, ${ }^{326}$ the fallout of World War II hastened the pace of change. In the wake of the Nazi horrors, there was a "most radical" shift as many commentators abandoned their unquestioning "reverence" for absolute sovereignty. ${ }^{327}$ It became increasingly apparent that traditional notions of sovereignty had to be modified, particularly in instances when significant outside intervention was required to protect people from gross human rights violations. ${ }^{328}$ Consequently, the doctrine of sovereignty was changed dramatically by the arrival of the United Nations on the scene and related institutions bent on promoting and securing universal human rights. ${ }^{329}$ After the debut of the post War human rights institutions, matters such as "the proper limits of state sovereignty" increasingly became the central focus of most international institutions. ${ }^{330}$

It is often said the domain of international human rights is, among other things, an on-going and escalating "attack upon the concept of state sovereignty as traditionally conceived" involving among other entities, "a spirited movement" of nonstate actors that transcend political boundaries. ${ }^{331}$

323. See Robert Keohane, International Institutions, in KRATOCHWIL \& MANSFIELD, supra note 168 , at 55 .

324. See STOETT, supra note 2, at 42 . This perspective is inspired by a core of liberal values which at the very least suggests "a sense of universal justice at the individual level." Id.

325. HOFFMAN, supra note 288 , at 46.

326. See HUMAN RIGHTS IN THE WORLD COMMUNITY, supra note 285, at 4.

327. See id. at 2.

328. See id. at 4.

329. See id.

330. See id. at 4-5.

331. See id. at 3. In addition, the "ever expanding and ever accelerating program" of "political and legal struggle" dubbed international human rights also involves "a goal setting agenda for global policy" as well as norms by which to assess national behavior and state legitimacy. HUMAN RIGHTS IN THE WORLD COMMUNITY, supra note 285, at 2. 
Notwithstanding their low death rates, ${ }^{332}$ states will face greater challenges going forward, including continual erosion or diminution of sovereignty.

As recent practice in international diplomacy with respect to global problems such as AIDS is revealing, the traditional distinction between state versus civil society is no longer tenable in international relations theory and practice. $^{333}$ The conceptually disparate spheres are increasingly "so interpenetrated" that the concepts are "only very vaguely and imprecisely indicative of distinct spheres of activity." 334

As territorial boundaries become more "porous" and as modern communication and transportation technologies proliferate, John W. Burton's "billiard-ball-like states" 335 are headed the direction of the dodo and the mastodon. The pace of change will accelerate as we enter the era of postinternational politics, marked by a tangled web of escalating interactions fusing both the domestic and international level. ${ }^{336}$ The hyper-linked emerging transnational networks of state and non-state actors "see politics on the surface of the earth as an integrated process operating in a single community.",337

332. WALTZ, supra note 173 , at 95 .

333. Robert W. Cox sees a blurring of international/domestic dichotomies. See Robert W. Cox, supra note 168 , at 344 . There is a need for interdisciplinary and interdepartmental approaches that study "intermestic" approaches. See id. Restructuring institutions of higher education to confront this erosion of boundaries is arguably one of the greatest challenges for higher education leaders in the twenty-first century.

334. Cox supra note 168 , at 344.

335. See HUMAN RIGHTS IN THE WORLD COMMUNITY, supra note 285 , at 12 . Burton's allusion refers to impregnable fortress-like states, impervious to anything except influence wielded by states of equal or greater capability. See INTERNATIONAL CONFLICT RESOLUTION, THEORY AND PRACTICE 18-19 (Edward A. Azar \& John W. Burton eds.) (1986).

336. See James N. Rosenau, Turbulence in World Politics: A THEORY of Chance AND CONTINUITY 6 (1990). The era of postinternational politics is defined by a global system that is characterized by increasing interactions between diverse actors including non state actors, various international organizations, financial markets, multinational corporations, terrorists, revolutionaries and a wide range of transnational and social religious and fundamentalist movements. See id. See also DoUgherTy \& PfaltZGrafF, supra note 285, at 543-44. See generally, LINKAGE POLITICS: ESSAYS ON THE CONVERGENCE OF NATIONAL AND INTERNATIONALSYSTEMS (James Rosenau ed., 1969); Rosenau, Compatibility, Consensus, and an Emerging Political Science of Adaptation, AMERICAN POLITICAL SCIENCE REVIEW, LX1(3), 983-88 (Dec. 1967); Wolfram F. Hanrieder, Compatibility and Consensus: A Proposal for the Conceptual Linkage of External and Internal Dimensions of Foreign Policy, AMERICAN Political SCIENCE Review, LX1(3) 971-82 (Dec. 1967). See DougherTy \& PfaltzGrafF, supra note 285 , at $\mathbf{5 7 4}$ (for a list of sources or works on the new realm of post-international politics). See generally Spectar, Saving the Ice Princess, supra note 189 (arguing that certain transnational non-state actors will have a greater ability to impact the process of international law and treaty-making going forward).

337. See HUMAN RIGHTS IN THE WORLD COMMUNITY, supra note 285, at 12 (citing Christopher Hill, Implications of the World Society Perspectives for National Foreign Policies, in CONFLICT IN WORLD SOCIETY: A NEW PERSPECTIVE ON INTERNATIONAL RELATIONS 174-91 (Michael Banks ed., 1984). 
Even if sovereignty is not completely destroyed, the on-going assaults ${ }^{338}$ by emerging trends in the global system are effectuating a de facto re-shaping of the institution. As Sir Hersch Lauterpacht had observed, the dominant trend of the last half of the twentieth century involved the sovereign state giving way to the "sovereignty of humankind." ${ }^{339}$ For Lauterpacht, the recognition of human rights in the post World War II era was "a brake upon exclusive and aggressive nationalism, which is the obstacle, both conscious and involuntary, to the idea of world community under the rule of law." ${ }^{340}$ The process of fundamental re-conceptualization of sovereignty that 'began' in the immediate post war era continues to gather momentum as it is catalyzed by a convergence of forces and processes in the age of bio-globalization.

Although Article 2(7) of the UN charter appears to firmly proscribe intervention of internal matters of states, new interpretations of that provision may be emerging in the age of globalization. In fact, many concede that definitions of the "sovereign rights of states" or what is "essentially within the domestic jurisdiction" are continuously changing. ${ }^{341}$ To cope with the new dilemmas of sovereignty and article $2(7)$ in the age of globalization, international lawyers, publicists and other commentators need to revise and update their understandings of sovereignty.

Some publicists and commentators are already taking up the challenge of re-working sovereignty for a new day. Ivan Simonovic argues that, in the age of globalization, "the old paradigm of international relations," based on assumptions about autonomous sovereign states that only factor their national interest calculations "does not reflect the present reality of international relations." ${ }^{342}$ Simonovic puts forth a new conception of sovereignty that builds on the concept of the equality of states: as globalization constrains states and transforms patterns of interactions between individuals, states, and international organizations, the principle of the sovereign equality of states should be transformed into the "principle of equally reduced sovereignty.",343 Simonovic endorses the role of international law and organizations in the governance of globalization, particularly with respect to threats such as environmental degradation, international crime, terrorism, AIDS, and human rights violations. ${ }^{344}$ In this context, Simonovic argues UN involvement is a necessary and "significant step" in managing the problems associated with

338. See HUMAN RIGHTS IN THE WORLD COMMUNITY, supra note 285 , at 2.

339. See id. at 3.

340. See id. (citing HERSCH LAUTERPACHT, INTERNATIONAL LAW AND HUMAN RIGHTS 47 (1973)).

341. See, e.g., Evan Luard, Human Rights and Foreign Policy, in HUMAN RIGHTS IN THE WORLD COMMUNITY, supra note 285, at 243.

342. Ivan Simonovic, State Sovereignty and Globalization: Are Some States More Equal, GEORGIA J. INT'L \& COMP. L. 381,391 (2000).

343. See id. at 403.

344. See id. at 402. 
rapid globalization. ${ }^{345}$ There is clearly a need for additional innovative thinking and scholarship that views sovereignty in new ways, including holistic interdisciplinary approaches that reconcile national, international, and human interests.

\section{International Security}

The invigorated global response to AIDS was possible largely as a result of the broadening of the definition of security. To form a global consensus about the need for concerted international action, members of the Security Council discarded traditional notions of security, recasting the concept in light of exigent realities as well as alternative visions of the future. Given the exigencies of the pandemic, proponents of the resolution contended members had to be willing to "see security through a new and wider prism, and forever after, think about it according to a new, more expansive definition." 346 Although AIDS was not "an issue of strategic security in the classic sense," 347 proponents argued that world community needed to "reshape" thinking about definitions of security. ${ }^{348}$

It was also apparent that unless the matter could be defined in ways that suggested a legitimate role for the Security Council, the Members would not agree that it was appropriate for the Council to discuss a health issue, much less pass a health-only resolution. ${ }^{349}$ It was therefore necessary to redefine the AIDS issue in such a way that UN members could make the case that the UN was acting within its constitutional mandate. The task was rendered more difficult because UN founders did not envision, nor provide explicitly, a role for the UN in matters of health. Customarily, matters related to health and other social issues are generally considered to be within the competence of the World Health Organization or reserved for the Economic and Social Council. ${ }^{350}$ In effect, throughout its history, the Council confined itself to a "classic security agenda built upon common efforts to resist aggression, and to stop armed conflict." 351 Until the development and acceptance of a broader vision of security, it was unlikely that AIDS would be accepted as an appropriate subject for a high level Security Council discussion. ${ }^{352}$

Prior to and during Council debate, more and more world leaders endorsed a "new agenda for world security" that involved a redefinition of

345. See id. at 402-03.

346. Press Release, Debate on Impact of AIDS, supra note 58.

347. See Vice President Al Gore, supra note 54.

348. See id.

349. See Remarks Following Vote, supra note 78.

350. As the proponents averred, the Security Council's involvement did not in any way "undercut" the work of the Economic and Social Council, but instead, reinforced it. See id.

351. Press Release, Debate on Impact of AIDS, supra note 58, at 3.

352. See Remarks Following Vote, supra note 78. 
international security. ${ }^{353}$ The new agenda included low politics issues such as the environment, drugs, poverty, development, terrorism, AIDS, and other pandemics. ${ }^{354}$ There was significant consensus on the urgency of embracing a more expansive view of international security that made the necessary interconnections between oft-separated areas such as development, peace, and disease. ${ }^{355}$ The members were challenged to realize that in the pandemic era, security had taken on a new and equally pressing meaning. In particular, James Wolfensohn of the World Bank urged the international community to "think beyond battalions or borders" when thinking about security. ${ }^{356}$ Wolfensohn called on all to focus on "human security," to increase the efforts aimed at winning the battle against poverty. ${ }^{357}$

We will be judged on whether we understand the nature of human security and sustainable development ... Security develops from within societies. If we want to prevent violent conflict, we need a comprehensive, equitable, and inclusive approach to development. A culture of prevention needs to permeate our work. Security, empowerment and opportunity must be recognized as key to freedom from poverty - just as freedom from poverty must be recognized as key to security. ${ }^{358}$

In his usually trenchant prose, Holbrooke summed it up thusly: "postCold War international security is about more than guns and bombs and the balance of power." 359

It was necessary to think of international security in broader terms, in terms that legitimized the Council's intrusion into the health matters of Members - in seeming disregard for article 2(7) of the Charter. The efforts to rethink security were so successful that some members resorted to hyperbole, dubbing AIDS an "aggressor." ${ }^{360}$ In urging a re-conceptualization of security, a UN representative argued that the pandemic was the functional equivalent of an armed aggressor and ipso facto,

353. Press Release, Debate on Impact of AIDS, supra note 58, at 2.

354. Id. at 2.

355. See infra notes 106-12.

356. See Wolfensohn, supra note 11. See also Press Release, Debate on Impact of AIDS, supra note 58. (Address by James D. Wolfensohn) (noting that when we think about security, "we must think beyond battalions or borders. We must think about human security, about winning a different war, the fight against poverty.").

357. See Wolfensohn, supra note 11.

358. Id. at 1.

359. See Statement for the Record, supra note 96. See W. Michael Reisman, International Law After the Cold War, 84 AM. J. INT"L L. 859 (1990).

360. See Vice President Al Gore, Remarks at U.N. Security Council Session on AIDS in Africa, available at http://www.un.int/usa/00_002.html (last visited Jan. 10, 2002) (analogizing AIDS to an aggressor against women's human rights). 
deserved no less attention in the Security Council than the use or threat of nuclear weaponry. . AIDS and armed conflict, with all their impact on Africa, should be accorded the status of an international security agenda item, falling within the competency of the Security Council. ${ }^{361}$

In sum, in light of the new consensus about international security, it was argued that the machinery of the United Nations "created to stop wars" should now be summoned in a "common cause, to defeat a common foe" - the AIDS virus. ${ }^{362}$

The passage of the resolution constituted "a benchmark in the evolution of the Security Council," ${ }^{363}$ as well as the recognition of the changed environment. In effect, the vote was a "recognition that AIDS is as great a security challenge" as any other conventional security threat in UN history. ${ }^{364}$

\section{International Cooperation: A Revolution of Indeterminate Obligations?}

The resolution sparked a heightened level of international cooperative activity and coordination that in turn have given rise to further expectations about future cooperation about a wide range of joint problems. The resolution also had a transformative and normative impact on international diplomatic discourse, fueling an intensified and unprecedented level of cooperation and coordination regarding global health. Supporters saw the resolution as "only a beginning" ${ }^{365}$ and they hoped similar resolve would be exhibited in upcoming UN fora. In particular, the stage was set for Members to "take further action" at the upcoming Millennium Summit and in the General Assembly's special session on HIV/AIDS. ${ }^{366}$

As expected, the UN General Assembly followed the Security Council's lead by adopting the "Declaration of Commitment on HIV/AIDS," adopted during the General Assembly's Special Session on June 27, 2001. The General Assembly called on members to ensure, by 2003 , the

361. See Press Release, Debate on Impact of AIDS, supra note 58, at 19 (comments of Mr. Arthur Mbanefo, the Nigerian representative).

362. Vice President Al Gore, supra note 54. Many civic groups are increasingly identifying HIV in militant terms. Former Congressman Dellums exhorted participants at a conference to "view the crisis of AIDS in Africa as the moral equivalent of a war being waged on millions of human lives." International AIDS Economics Network, A Continent in Crisis: Africa and the AIDS Pandemic, available at http://www.worldbank.org/aidsecon/africa/global.htm (last visited May 20, 2000). In addition, Mr. Dellums challenged the audience to "mobilize a new peace movement to end this war." Id.

363. See Remarks Following Vote, supra note 78.

364. See id.

365. See id.

366. See id. 
inclusion of HIV/AIDS awareness and training, including gender component, into guidelines designed for use by defence personnel and other personnel involved in international peacekeeping operations while also continuing with ongoing education and prevention efforts, including predeployment orientation, for these personnel. ${ }^{367}$

The resolution further urged members to:

develop and begin to implement [by 2003] national strategies that incorporate HIV/AIDS awareness, prevention, care and treatment elements into programmes or actions that respond to emergency situations... and, where appropriate, factor HIV/AIDS components into international assistance programmes. ${ }^{368}$

With respect to national security, the resolution exhorted members to have in place by 2003 ,

national strategies to address spread of HIV among national uniformed services, where required, including armed forces and civil defence force, and consider ways of using personnel from these services who are educated and trained in HIV/AIDS awareness and prevention to assist with HIV/AIDS awareness and prevention activities including participation in emergency, humanitarian, disaster relief and rehabilitation. ${ }^{369}$

To realize the goals in the both the Council's resolution and the UNGA declaration, the UNAIDS Secretariat established a global initiative on HIV/AIDS and security with the goal of strengthening partnerships with cosponsors, especially in areas plagued by conflict. ${ }^{370} \mathrm{UN}$ efforts to stem the pandemic intensified following the resolution, as evidenced by the dissemination of hundreds of thousands of condoms to peacekeepers in wartorn areas around the world. ${ }^{371}$

367. See HIV/AIDS and Conflict, supra note 3. See also UNAIDS Initiative on HIV/AIDS and Security, supra note 3. To achieve this target, UNAIDS initiatives will focus on peacekeeping operations including, ANAMSIL (Sierra Leone), UNMEE (Eritrea/Ethiopia), MONUC (Democratic Republic of Congo), UNMIK (Kosovo), and UNTAET (East Timor).

368. See UNAIDS Initiative on HIV/AIDS and Security, supra note 3.

369. See id.

370. See id.

371. See First Health-Only Resolution, supra note 69. 
.Other UN agencies including the Economic and Social Council (ECOSOC), the UN Development Program (UNDP), UNAIDS, and the office of UN Secretary General Annan also pledged to develop a collective and coordinated response to the problem of AIDS and conflict. ${ }^{372}$ At the World Bank, James Wolfensohn pledged to work with the Security Council on a range of security issues related to the AIDS pandemic. ${ }^{373}$ World Bank President James Wolfensohn pledged to focus on a range of human security issues as part of an overall strategy to prevent violent conflict. Wolfensohn called for "a comprehensive, equitable and inclusive approach to development" that is focused on assuring "freedom from poverty," a critical element of human security. ${ }^{374}$

International efforts to stem the pandemic gathered momentum around the world. Some of the more important gatherings included the 2000 African Development Forum meeting and the Organization of African Unity Summit on HIV/AIDS, Tuberculosis and Other Related Infectious Diseases in April 2001 as well as regional efforts in Lake Chad Basin and West Africa. ${ }^{375}$ Collaborative efforts between state and non-state actors such as the International Partnership against AIDS in Africa have intensified the leveraging of resources to galvanize national and local action on HIV/AIDS. ${ }^{376}$ At least nineteen African countries have set up high-level national AIDS councils or commissions; thirty-four African countries have completed national strategic AIDS plans and seven more plans are near completion. ${ }^{377}$

What was even more impressive about this heightened level international coordination was the focus on Africa-a continent that is not traditionally

372. See Statement for the Record, supra note 96.

373. See Wolfensohn, supra note 11 , at 1.

374. Id. Some have argued that the international community address the issues of chronic poverty in tandem with fighting AIDS. See, e.g., Spectar, Hybrid Horseman, supra note 13, at 284-94 (advocating the adoption and implementation of a 'holistic development framework' designed to contain 'the syndrome of chronic poverty as a disease vector'). The implementation of the holistic development framework requires, inter alia, a serious treatment of the right to holistic development. Id . at 284 . The right to development is the individual and peoples' collective right to participate in and derive benefit from a sound development policy based on the satisfaction of material as well as non-material human needs or wants. See Karin Mickelson, Rhetoric and Rage: Third World Voices in International Legal Discourse, 16 WIS. INT'LL. J. 353, 376 (1998) (citing Hector Gross Espiell, The Right to Development as a Human Right, 16 TEX. INT'L L. J. 189 (1981)). The right to development includes the collective right of countries to a just, equitable, and sustainable international economic framework, without the structural barriers that constitute impediments to full development. Id. See also, Stephen P. Marks, Emerging Human Rights: A New Generation for the 1980s? 33 RUTGERS L. REV. 435, 445 (1981). Some suggest the right to development is effectively a "precondition" to the enjoyment of other basic rights, including liberty and justice. See, e.g., Satvinder Juss, Global Environmental Change: Health and the Challenge for Human Rights, 5 IND. J. GLOBAL LEGAL STUD. 121, 157 (1997) (citing MOHAMMED BEDJAOUI, THE RIGHT TO DEVELOPMENT IN INTERNATIONAL LAW: ACHIEVEMENTS AND PROSPECTS 1177, 1182 (1991)).

375. Report on the Global HIV/AIDS Epidemic 2000, supra note 131.

376. See id.

377. See id. 
considered to be of great relevance with respect to the national security calculations of Great Powers. ${ }^{378}$ U.S. leadership on this world interest issue was a fine example of the integration of national and international interests. In addition to the interests listed above, the U.S. posture also served the goal of showing commitment to Africa at a time when U.S. Congress members and AIDS activists were becoming restive. It was thought that showing such leadership during the "Month of Africa" was a sign that America was once again reasserting its power and influence in the $\mathrm{UN} .{ }^{379}$ In lauding the resolution, members gave credit to the United States, with one representative expressing hope that "the pioneering initiative of the United States will be pursued by others in justified earnestness." 380

By highlighting international attention on African issues in the Security Council discussion of AIDS, development, and war, the Council was helping to "put to rest the canard that Africa doesn't matter; to refute the belief that the international community has one set of rules for Europe or Asia and another for Africa." ${ }^{381}$ It was hoped that the Council's action would precipitate worldwide attention to the needs of Africa in the throes of the global AIDS crisis. $^{382}$ Proponents of the resolution also expected that the new focus on African conflict zones would lead the UN to "assist African governments in devoting more resources to tackling economic and social problems," and thereby ameliorate the epidemic. ${ }^{383}$ Similarly, others hoped that the Council's involvement could "provide the moral and political commitment" needed to secure resources to support civil society initiatives efforts such as the International Partnership Against AIDS in Africa. ${ }^{384}$

The intensified cooperation was also born out of a re-learning of the truism regarding the interconnectedness of the human condition, especially as a result of new communications technologies and the realities of bioglobalization. Thus, James Wolfensohn exhorted the international community to "mobilize" not just for a "war against AIDS," but for "a war for Africa's future and for our own." 385 Similarly, Mark Malloch Brown, Administrator of UNDP, argued that the international community needed to take concerted action because failure to act could endanger everyone: "Today, this is Africa's

378. Despite its politically incorrect overtones, the words Great Powers, unlike other euphemistic latter day substitutes remains most apt as it continues to symbolize the vast and growing disparities in power and wealth between the so-called Northern or Western industrialized countries vis a vis Africa and the rest of the Third, Fourth, and Fifth Worlds.

379. See Statement During the Open Meeting on the Month of Africa, supra note 247. As Holbrooke stated in characteristic style, it was a sign "America is back." Id.

380. Press Release, Debate on Impact of AIDS, supra note 58, at 7.

381. See Holbrooke, supra note 247.

382. See Remarks Following Vote, supra note 78.

383. Press Release, Debate on Impact of AIDS, supra note 58, at 7. (Comments of Libertine Amathila, Namibia's Minister of Health and Social Services).

384. See id. at 12.

385. Wolfensohn, supra note 11 , at 6 . 
drama... unmet, it becomes the world's." ${ }^{\text {386 }}$ As Secretary General Annan stated, "In the war against HIV/AIDS, there is no us and them, no developed and developing countries, no rich and poor-only a common enemy that knows no frontiers and threatens all peoples., 387

In sum, the Security Council debate sparked an enthusiastic response from members as well as a range of actions and optimistic obligation-laden proposals to counter the pandemic. Many expect that in going forward, the Security Council, UNAIDS, and other international agencies would play an even more activist role in coordinating the efforts to combat and contain AIDS and other the pandemics. Potential roles for the UN could include the establishment of a Security Council mechanism for close cooperation and coordination with UNAIDS, involving regular open briefing sessions with the Executive Director of UNAIDS; ${ }^{388}$ reinforcing UNAIDS through a "strengthened mandate, greater resources and enhanced coordinating authority for its Executive Director;", 389 the creation of a central register or clearinghouse to monitor and harmonize global efforts to fight the pandemic; ${ }^{390}$ a UN campaign to raise funds by "assessing contributions to Member States according to their economic level"391 as well as voluntary "contributions by universities, research centres, companies, NGOs and individuals." ${ }^{392}$ The Security Council resolution and subsequent proposals for greater cooperation derived thereunder generally received broad support, notwithstanding concerns about sovereignty and intervention

In the euphoria of the moment, UN representatives seemingly sought to outdo one another in touting this new era of cooperation. One UN representative saw the new cooperative relations in terms of international legal or moral obligation, maintaining that the world community "owe[s] it to the African people affected by this scourge to deploy every means necessary to defeat the pandemic and transform a legacy of despair into an endowment of hope." ${ }^{\text {393 }}$ The new and broader vision of human security was touted as the true dimension of security ${ }^{394}$ as opposed to the narrower or constricted antiquated

386. Press Release, Debate on Impact of AIDS, supra note 58, at 5 (Malloch Brown, Administrator of UNDP).

387. Foreword by Secretary General Annan to Declaration of Commitment on HIV/AIDS, available at $\mathrm{http}: / / \mathrm{www}$.unaids.org/UNGASS/docs/AIDSDeclaration-en.pdf (last visited Sept. 20, 2002).

388. Press Release, Debate on Impact of AIDS, supra note 58 (Representative Lee SeeYoung, the Republic of Korea).

389. See id. at 15.

390. See id. at 11 (Sir Jeremy Greenstock, the British representative). Peter Piot, the Executive Director of UNAIDS pledged in January 2000 to intensify such clearinghouse efforts within the UN to assure the flow of current information to all members). See id. at 17.

391. Press Release, Debate on Impact of AIDS, supra note 58, at 15 (Abuzed Omar Dorda, the Libyan ambassador to the UN).

392. See id. at 15.

393. See id. at 17 (Sergio Vento, the Italian representative).

394. See id. at 7. 
notions. In this new epoch, the international community had to credibly address issues of development because it was clear "the world would not be a secure place if women and children had no security of their individual self." ${ }^{395}$ Another delegate member noted the link between peace and development, calling them "two sides of the same coin;" true peace was impossible without "economic and social progress for all people." 396 The Malian delegate remarked that peace and security "depended on the socioeconomic realities of nations" - not just on the absence of war. ${ }^{397}$ Since AIDS "truly threatened the very basis of human security," an effective war against AIDS was a precondition for peace and sustainable development in Africa. ${ }^{398}$

As many UN representatives spoke eloquently about the new-fangled dawn of intensified international cooperation, they unwittingly gave credence to the views of those who felt the UN system was overreaching. While these holistic visions of international security and enhanced international cooperation may indeed augur well for the future of humankind, some observers were alarmed by the prospect increasingly activist international organizations. Below, the Article examines some of the concerns triggered by this new revolution of expanding and indeterminate obligations.

\section{E. Intervention \& Humanitarian Intervention}

Given the expanded commitments, expectations and potential obligations that could be triggered by a UN resolution on a health-only matter, some commentators were concerned the Security Council resolution could infringe on national sovereignty. Several countries raised objections to what they viewed as U.S.-led interference in their internal affairs. ${ }^{399}$ The Russian and the Indonesian delegates were especially skeptical of U.S. motives, expressing concerns that the resolution may be used to infringe upon the sovereignty of UN member states. ${ }^{400}$ As the Indonesian representative to the UN stated, "My delegation holds the view that linking HIV to international peacekeeping operations raises serious questions." nations provide peacekeeping troops complained that the U.S., which had relatively fewer UN peacekeeping soldiers, was overstepping its bounds by trying to use the Security Council resolution to mandate training and education for others. ${ }^{402}$

395. Id. (Anwarul Karim Chowdhury of Bangladesh).

396. See id. at 10 (Argentinean delegate, Arnoldo Manuel Listre).

397. Press Release, Debate on Impact of AIDS, supra note 58, at 12 (Moctar Ouane, the representative of Mali).

398. See id. at 16 (Jargalsaikhany Enkhsaikhan of Mongolia).

399. First Health-Only Resolution, supra note 69.

400. See id.

401. See id.

402. See id. While the U.S. provided about $800 \mathrm{UN}$ police officers and observers, it did not at the time have any UN peacekeeping soldiers. See id. 
Likewise, some in the U.S. are inherently suspicious of what they perceive to be UN activism, particularly far reaching resolutions that could threaten sovereignty and usurp independence. There is simmering bitterness and even resistance from certain quarters in the far right of the political spectrum against creeping cosmopolitanism and the purported loss of precious sovereignty. In particular, some fear that U.S. participation in international organizations and treaties, even for humanitarian reasons is eroding national sovereignty. ${ }^{403}$ This phobia regarding international organizations is intensified when it appears to some that these agencies are deviating from their narrowly focused traditional missions. ${ }^{404}$ For diehard adherents of this perspective, coeval international organizations are heedlessly "shifting rapidly towards an activist, internationalist agenda" that undermines U.S. sovereignty in favor of a hostile Third World majority. ${ }^{405}$ Under this view traditional conceptions of sovereignty, and constitutional governance are purportedly "being subjugated to self-anointed 'intellectually progressive' and vague concepts of international responsibilities and control." ${ }^{406}$

Proponents of the resolution were quick to reject the contentions that the resolution was a tool for illegitimate and unwarranted intervention. They argued that rather than infringe "on sovereignty or authority of countries," the resolution merely reflected the "collective will of the Security Council." Further, it was argued that resolution was fully within the competence and jurisdiction of the Council. The resolution focused "appropriately on the area where the Security Council has the primary responsibility and the most at stake," to wit, the impact of AIDS on peacekeeping" 408 Rather than usurping powers, the resolution was simply a legitimate extension of Security Council "interest into a field that had previously not been considered." 409 Proponents argued the resolution was not all that different from other council resolutions. Like other Council resolutions, this one too was simply designed "to galvanize international action to meet common threats" - the quintessence of one of the primary purposes for which the UN was founded. ${ }^{410}$ As further evidence of their sensitivity towards the institution of sovereignty, proponents pointed to the limited nature of the resolution and its narrow focus on peacekeeping.

403. See, e.g., Bob Barr, Protecting National Sovereignty in an Era of International Meddling: An Increasingly Difficult Task, HARV. J. ON LEGIS. 299 (2000).

404. See generally id.

405. See id. at 299. Some warn that U.S. foreign policy has effectuated a "de facto amendment" of the U.S. Constitution with disregard of the procedural and substantive protections of the democratic process. See id.

406. See id. at 300. Barr blames the "elite and academe" for advocating an "activist and paternalistic U.N."

407. See Remarks Following Vote, supra note 78.

408. See id.

409. See id.

410. See id. 
The resolution also raises, albeit obliquely, the question and the prospect of humanitarian intervention on behalf of AIDS victims. Humanitarian intervention has been defined as proportionate transboundary help, including forcible help, provided by governments to persons in another state who are being denied fundamental human rights and who themselves would be rationally inclined to rebel against their oppressive government. ${ }^{41}$ As some commentators have argued, humanitarian intervention is legitimate and even necessary in cases involving "genocide, famine, etc. [sic]." ${ }^{412}$ It is no surprise then that for some, the resolution (or perhaps its penumbras) evoke the specter of forcible UN humanitarian intervention on behalf of AIDS victims.

The doctrine of humanitarian intervention remains very controversial. Opponents of the doctrine worry that due to many "inherent difficulties and costs," there is "little consistency in the practice of intervention" and weak states are far more likely to be victims of intervention than powerful states. ${ }^{413}$ Others worry humanitarian intervention could become a ruse for "gratuitous interference in the internal affairs of sovereign states." 414

The practice has very strong advocates, including Mr. Kofi Annan, the UN Secretary General. In remarks that generated some controversy, Mr. Annan advocated the use armed forces in humanitarian interventions to stop mass murder and egregious violations of human rights-a position that has generated significant controversy among UN members. ${ }^{415} \mathrm{Mr}$. Annan maintains that when crimes against humanity occur and "peaceful attempts to halt them have been exhausted, the Security Council has a moral duty to act on behalf of the international community." ${ }^{, 46}$ As the Secretary-General argues, the fact that the international community cannot protect people everywhere is "no reason for doing nothing when we can." 117 Unlike intervention for selfdetermination, humanitarian intervention goes above the principle of sovereignty as it acknowledges certain basic human rights, including the right to life, which "transcends the limits of the state." 418

411. For a good discussion of the concept of humanitarian intervention and the acceptability of the use of force to achieve it, see, e.g., FERnANDO R. TESON, HuManITARIAN INTERVENTION: AN INQUIRY INTO LAW AND MORALITY (1988). Teson argues that from an "ethical standpoint" governments are mere agents of the people, "their international rights derive from the rights of the individuals who inhabit and constitute the state." Id. From this position, Teson justifies forcible unilateral humanitarian intervention and penetration of a sovereign state's borders to protect egregiously aggrieved peoples. Id. In reaching this position, Teson rejects the premises of the noninterventionist model of international law and international relations and with it, the primacy of the Hegelian statist myth. Id.

412. HOFFMAN, supra note 288 , at 64 .

413. Id.

414. Annan, supra note 16 , at 47.

415. See id.

416. See id.

417. See id.

418. HoFFMAN supra note 288 , at 64 . 
Since humanitarian intervention is acknowledged as a very clear exception to the principle of sovereignty, ${ }^{419}$ the resolution may be viewed as laying the foundation for subsequent efforts to engage in potentially intrusive interventions on behalf of AIDS victims. In effect, the notion that AIDS is a genocide-like threat to international security opens up intriguing possibilities with regard to humanitarian intervention by the international community in support of the victims. It is feared that this seemingly benign encroachment into health matters-matters essentially within the domestic jurisdictioncould open the door to even more invasive interventions-including perhaps measures under Chapter VII of the Charter.

As far-fetched as it sounds, the prospect of forcible intervention by international organizations on behalf of disease sufferers is not entirely without precedent or historical analogy. Ram Dass and Paul Gorman have written about a dramatic episode during the small pox eradication campaign where an international immunization team invaded an Indian household in the night to "forcibly vaccinate a family against their will." 420

These concerns notwithstanding, supporters of the resolution aver that the UN, even with the resolution, could not "require member states to force involuntary testing of their troops," as such a move "would violate the United Nations' respect for national sovereignty." ${ }^{421}$ However, it is not clear how the Security Council would deal with a very high HIV-prevalence country whose government staunchly and systematically refuses to cooperate with international agencies on implementing the peacekeeping resolution. Regardless of how these questions are eventually resolved, it is clear that the Security Council resolution on AIDS has significantly reshaped coeval understandings of Article 2(7) of the UN Charter that prohibits the UN from encroaching into "matters essentially within the domestic jurisdiction" of Member States.

\section{A Permanent ShIFT? A Note on Bush Administration Policies}

It was feared that the new administration of George W. Bush would rethink U.S. interests in Africa and sharply reverse Clinton's pro-Africa policies. One analyst predicted a Bush presidency would mean a return to the "blatantly anti-African policies of the Reagan-Bush years, characterized by a general disregard for black people and a perception of Africa as a social welfare case." ${ }^{422}$ Unlike candidate Gore's policy advisers and likely

419. See id. at 63.

420. See Barry S. Levy, Lecture: Twenty-First Century Challenges for Law and Public Health, 32 IND. L. REV. 1149, 1151 (1999) (discussing RAM DASS \& PAUL GORMAN, How CAN I HELP?: STORIES AND REFLECTIONS ON SERVICE (1985)).

421. See Remarks Following Vote, supra note 78.

422. Salih Booker, The Coming Apathy: Africa Policy Under a Bush Administration, available at http://www.africaaction.org/docs00/bush0012.htm (last visited Oct. 10, 2000). 
appointees for positions such as Secretary of State, ${ }^{423} \mathrm{Mr}$. Bush was seen as surrounding himself with experts who had shown little interest in African issues, besides oil. ${ }^{424}$ Suspicion turned into paranoia when Mr. Bush named Dick Cheney as his vice president; critics quickly noted that in 1986, Cheney was among the minority of mostly republican members of Congress who had voted to oppose the release of Nelson Mandela from prison. When Mr. Bush was asked about his foreign policy regarding Africa during the second presidential debate, he offhandedly remarked: "There's got to be priorities."425

Notwithstanding these ominous portents, AIDS and other infectious diseases have emerged as a major priority in the global security agenda of the Bush administration - at least pre-September 11th. Fueled by the leadership of Secretary of State Powell, the U.S. government continued and even expanded Clinton era foreign assistance to combat AIDS. Confounding administration detractors and critics, Secretary of State Powell stated in Spring 2001: "There is no war causing more death and destruction, there is no war on the face of the earth right now that is more serious, that is more grave, than the war we see here in sub-Saharan Africa against HIV/AIDS." ${ }^{\text {426 }}$ In May 2001, the President announced the United States has the "power to help" and pledged that the U.S. is "committed to working with other nations to reduce suffering and to spare lives." ${ }^{\text {"427 }}$ President Bush has followed up his words with concrete steps and policy proposals. The Administration established a cabinet-level

423. See CNN.com, available at http://www.cnn.com/2000/Health/AIDS/04/30/aids .threat.03/ (last visited June 22, 2000). One of Mr. Gore's chief foreign policy advisers, Leon Fuerth, a progressive internationalist, had identified AIDS, terrorism, and environmental degradation as key threats to U.S. security and as centerpieces of a future Gore foreign policy. See id. With respect to AIDS, Fuerth argued that a coordinated global response was required, warning "It isn't as if this disease is going to stay put in sub-Saharan Africa." Id. In February 2003, Mr. Fuerth, at this writer's invitation, delivered a public lecture at the University of Scranton entitled "Is HIV/AIDS in Africa an American National Security Issue? A Discussion of America's National Security Interests in the Developing World." In a compelling presentation, Mr. Fuerth wamed that left unchecked, the ADS pandemic could lead to a breakdown of society and chaos that can threaten U.S. security. See Borys Krawczeniuk, Former Gore Advisor Links Terrorism, AIDS, THE TRIBUNE, Feb. 28, 2003, at A6. Furthermore, it was widely believed that had a few more dimple and pregnant chards broken his way, Mr. Gore would have appointed Leon Fuerth as his National Security Adviser and Ambassador Holbrooke as his Secretary of State. See id.

424. Booker, supra note 422. As Michael Westphal, Deputy Assistant Secretary of Defense for African Affairs stated, stability in the Africa is of great concern to the United States partly because the continent supplies $15 \%$ of U.S. oil. See Jim Garamore, U.S. Policy in Africa seeks Stability to Counter Terror, available at http://www.defenselink.mil/news/ Apr2002/n04022002_200204022.html (last visited May 15, 2002).

425. Booker, supra note 422.

426. AIDS and Violent Conflict in Africa: Special Report, Oct. 15, 2001, 6, United States Institute of Peace, available at http://www.usip.org/pubs/specialreports/sr75.html. See also Charles W. Corey, Powell Places Priority on War Against HIV/AIDS in Africa, Washington File, available at http://usinfo.state.gov/topical/global/hiv/01052703.htm (last visited May 27, 2001).

427. Fact Sheet: U.S. Leadership on Global Fund to Fight HIV/AIDS, Malrai and Tuberculosis, U.S. NEWS WIRE, July 20, 2001. 
HIV/AIDS Task Force co-chaired by Health and Human Service Secretary (Tommy Thompson) and Colin Powell; it also named Jack Chow to the newly created position of Deputy Assistant Secretary for International Health and Science. In May 2001, the president pledged $\$ 200$ million for the Global Fund to fight AIDS tuberculosis and malaria. ${ }^{428}$ In March 2002, on the eve of the Monterey Summit for Development, the U.S. announced a "compact for development" that included a pledge for an additional $\$ 5$ billion in development assistance (mostly grants) over the next three years. ${ }^{429}$ By June 2001, Secretary Powell was fully engaged in the global war against AIDS, leaving no doubt in the minds of observers that he considered the pandemic a threat to U.S. interests. Powell urged the UN to develop "comprehensive and coordinated efforts" to combat AIDS because posed a grave danger to international security. Sounding like very much like Holbrooke, Powell remarked:

AIDS is not just a humanitarian or health issue. It not only kills. It also destroys communities. It decimates countries. It destabilizes regions. It can consume continents. No war on the face of the earth is more destructive than the AIDS pandemic. ${ }^{430}$

Until September 11th and the necessary shift in U.S. overseas priorities, it appeared as if the realignment of national interests began in the Clinton administration was going to continue. As the Bush administration turned its attention to the global war on terror, attention to the AIDS pandemic fell off

428. See Bush Offers AIDS Help; Funds for African Relief Newsday, Associated Press, May 12, 2001.

429. See U.S. Health Secretary visits Africa on Disease Fighting, available at http://usinfo.state.gov/topica/global/hiv/o2040101.htm (last visited May 12, 2001). Nonetheless, even as the Bush administration was aggressively emulating the Clinton-Gore lead on this issue, the administration was being tugged to the right in certain areas. The administration was the only abstaining party when the fifty-three member UN Human Rights Commission voted on a resolution designed to improve access to AIDS drugs. See United States Abstains from Vote on AIDS Drugs Resolution, available at http://usinfo.state.gov/ topical/global/hiv/01042302.htm (last visited June 19, 2002) (However, the Commission itself lost a lot of credibility when it took the step of ousting the United States, even as human rights violators such as the Sudan were well ensconced). Additionally, some activists were concerned by what they perceived as a seemingly disproportionate focus on prevention, including abstinence, as opposed to treatment by key Bush administration officials. See id. Critiquing what he believed to be a cosmetic response to the gravest health threat in nearly a millennia, Tony Burdon, a senior policy adviser at Oxfam noted the world's richest nations had scrounged up "enough money for some prevention, but not a penny to treat the sick." Id. Additionally, the Bush administration mounted a fierce but unsuccessful campaign to defeat the treatment equity proposals by the developing countries at the Doha Ministerial Summit of the WTO in Nov. 2001.

430. Secretary of State Colin Powell, Address at the United Nations Special Session on HIV/AIDS June 25, 2001, available at http://www.state.gov/secretary/rm/2001/3756.htm (last visited Sept. 9, 2001). 
the radar screen. Even as the war on the global terror network remains on the front burner, Bush administration officials continue to view the fight against AIDS as an important U.S. national interest. Speaking in the post September 11 period, Paula Dobriansky, Under Secretary of State for Global Affairs stated that AIDS in Africa remains one of the administration's "highest priorities." ${ }^{\text {"31 }}$ During the 2003 State of the Union speech, Bush gave credence to this view when he stated that he would ask Congress for $\$ 15$ billion over the next five years, including nearly $\$ 10$ billion in new money to fight AIDS in Africa and the Caribbean. ${ }^{432}$ Bush's endorsement of a vigorous campaign to reduce the threat of AIDS "surprised many" 433 of his supporters and detractors alike. In a University of Scranton lecture discussing the threat of AIDS in Africa, Leon Fuerth remarked "Something has happened to the thinking of President Bush along the way... It may be the realization that chaos in other countries" increases the likelihood that these countries may become "bases for the operations of terror." ${ }^{, 34}$ Even as some skeptics questioned the President's commitment on the global AIDS issue, this writer saw Bush's pledge as further evidence of the continuing rethinking of 'security' and other concepts in international affairs-a process largely precipitated and accelerated by the Clinton-Gore team, including key advisers such as Richard Holbrooke and Leon Fuerth.

\section{CONCLUSION}

The concepts of national interest and sovereignty are not cast in stone, nor are they entombed in a hermetically sealed conceptual casket. In the course of the global response to AIDS, the international community questioned and re-assessed traditional understandings of national interest, security, and sovereignty, precipitating a new consensus about the synergies between national interest and international interest. In reaction to AIDS as a

431. "The Global Fight Against HIV/AIDS, Tuberculosis, and Malaria," Statement by Paul J. Dobriansky before Senate Foreign Relations Committee, Feb. 13, 2002. Similarly, Richard Holbrooke who continues the campaign as a private citizen hopes the U.S. would continue to focus on the pandemic and the threat it poses to U.S. interests. Holbrooke spoke to several Princeton University students who interviewed him in the course of preparing their final paper for a seminar taught by this author in spring 2002 (audiotape on file with author).

432. See $\mathrm{CNN}$, supra note 423 .

433. Id.

434. Id. Yet, as even many, including this writer thunderously applauded President Bush's maiden entry into the fray, some observers questioned Bush's credibility on this matter, suggesting that the President was merely planning to divert old money from other equally vital aid programs such as malaria control. In a scathing editorial for the New York Times, Princeton University economist Paul Krugman questioned Bush's program to fight AIDS in Africa, citing it as further evidence of the President's "mendacity," "record of broken promises," and "unfounded claims" that have "discredited the administration's foreign policy" and visited great harm on the reputation of the United States "in the eyes of much of the world." Paul Krugman, Threats, Promises and Lies Straining Bush's Credibility, THE SCRANTON TIMES, Feb. 26, 2003, at 4. 
transborder security threat, interstate cooperation on health issues is weakening traditional conceptual boundaries, placing into question the conventional meanings of national interest, sovereignty, and non-intervention. Efforts to understand these transformations in the international ecosystem are aided by flexible neoliberal institutionalist perspectives instead of the realists' static conceptions of interest and sovereignty.

The U.S. administration of Bill Clinton took a leadership role in rethinking and redefining U.S. national interests regarding international health, as well as in building global support for a campaign against AIDS as a security threat. In fact, an examination of the global response to AIDS as a security threat is also a case study about the role of U.S. as a force for good. It is apparent that in a uni-polar world dominated by an undisputed hegemon, with disproportionate resources, U.S. leaders have tremendous impact on the quality of world order. ${ }^{435}$ In that regard, the Clinton Administration strongly demonstrated the tremendous ability of the U.S. to be a force for good in the battle against AIDS.

The intensified global focus on HIV/AIDS as a security threat was spurred, in part, by a decisive rethinking of U.S. national interests with regard to international health and a more comprehensive view of nexus between national and international security, broadly conceived. Conceptions of national interest and security (traditional realist variables) were transformed by new understanding about the catastrophic potential of the AIDS, new knowledge about the processes of bio-globalization and visionary reflectivity regarding these new trends. New thinking about security in the vortex of the pandemic, ushered in a novel consensus about values intrinsic to the long term sustainability and governance of a nascent global society besieged by seemingly implacable microbial foes. With strong U.S. leadership, world leaders recognized AIDS as a major security crisis, and they placed the pandemic at the apex of global security agenda.

The nature and quality of coeval sovereignty is not static. As the international community developed targeted interventions designed to multilaterally respond to AIDS as a security issue, the institution of sovereignty underwent substantial transformation. The Security Council's engagement on the matter of AIDS and its relationship to conflict is arguably the clearest harbinger yet of a bold new challenge to the sacrosanct institution of sovereignty. The meeting and the ensuing resolution were key indicators of the changing assessments of national interest, international security, and the nature of sovereignty in the age of globalization. The Security Council's resolution on AIDS as well as the heightened level of cooperative synergies portend a significant-even a radical-transformation of sovereignty. The destructive threat of global pestilence effectively re-ordered state's valuations

435. See Spectar, supra note 158, at 1036 (suggesting that "like Atlas or the Archimedean lever," the U.S. can, and should, lead the world in resolving or managing the thorny global challenges of the twenty-first century). 
of sovereignty and curtailed states' resort to the use of sovereignty as a shield. By challenging the primacy of the state on "local" issues such as health, the global response to AIDS is a challenge to the institution of sovereignty. In effect, the emerging consensus that AIDS is a transborder security requiring sustained concerted responses laid the groundwork for more intensified interstate cooperation on health issues, and ipso facto, a loosening of the bonds of sovereignty. The transformation of the institution of sovereignty and its doppelganger, the principle of non-intervention, is further evidence of the limits of statecentrism and national-interest-based approaches to global problems.

The principle of non-intervention is equally being transformed by increasingly activist international institutions in the war against AIDS. The coordinated global response, especially the Security Council resolution, arguably opens the door for the 'intrusion' of the UN into even more spheres hitherto considered "matters essentially within domestic jurisdiction." This revivified internationalism has raised the dander of UN detractors and others suspicious of a brave new interventionist world order, marked by the erosion of national sovereignty. Despite its seemingly narrow focus, the overall thrust of the resolution and its long term implications portend an expansion of the scope and power of international institutions at the expense of state power. The global response to AIDS might in a sense be a precursor to bolder humanitarian interventions on behalf of victims of the four horsemen.

The heightened international coordination and cooperation on the AIDS problem is best explained by neoliberal institutionalist approaches, as opposed to conventional realism. Liberal institutionalists take a more flexible approach to concepts such as sovereignty and view them to be capable of modification in the interactive processes of interstate discourse and intercourse. The liberal institutionalist approach accounts for an evolutionary notion sovereignty and provides a viable framework for thinking about sovereignty and justice. To cope with the emerging threats of the twenty-first century, it will be increasingly necessary to reject the realists' prescriptions and to embrace a dynamic institutionalist perspective.

The inextricable linkage between global and human security further blurs the distinction between so called international and domestic issues and this is sure to spark further interest in the so called 'intermestic realm.' To the degree that the response to the AIDS pandemic fueled a new consensus about significance of 'intermestic' thinking regarding traditional concepts such as national interest, security, and sovereignty, the pandemic is altering the nature of diplomatic discourse and practice. Given the link between health and security, it would seem that the much-vaunted border between high and low politics is not so impervious after all. International lawyers and political scientists will need to develop new interdisciplinary or transdisciplinary approaches that capture the multidimensional dynamics of this new realm.

By blurring the distinction between matters of local versus global concern, the response to the AIDS pandemic is fueling a new reflective 
consensus on core conceptions such as national interest, security and sovereignty. Evidence of the new international consensus is evident in the intensified level of concerted action to come to the rescue of Africa - the vortex of the pandemic. Out of this has come a clear sense of the interconnectedness of the human condition, particularly as technological and socio-economic links demonstrate the relative smallness of the planet. This intensified and concerted response by a broad swath of states was an exemplar of international cooperation at the dawn of a new era. If the promise and momentum created by UN Security Council resolution is sustained, humankind may be at the threshold of a new era of international cooperation.

In its response to AIDS as a security issue, the international community took the first important baby step, transcending the shackles of statecentrism and venturing forth in the development of a viable normative framework for managing galloping globalization. Recognizing the limits of the statecentric system, world leaders opted for intensified cooperative and coordinated activity in the management of a common threat.

Looking ahead, sovereignty will continue to be eroded by increasingly prohibitive forms of intervention into conventionally internal matters. Significant derogations from sovereignty may be necessary and appropriate if the international community is going to successfully manage globalization. States will increasingly modify their conceptions of national interest to embrace a broader vision of 'world interest' and the concept of international security will continue to undergo sustained revision and transformation; likewise, the traditional doctrine of non-intervention will be increasingly limited in scope. ${ }^{436}$

436. The need for greater cooperation and coordination is made even more urgent today as the new specter of the new SARS epidemic stealthily stalks the planet. See HK Braces as Global Toll Mounts, at http://www.cnn.com/2003/HEALTH/04/06/sars.wrap/index.html (last visited Apr. 7, 2003). SARS or severe acute respiratory syndrome is a new communicable disease that reportedly originated from China's Guangdong province but that has spread rapidly to Hong Kong, Canada, and Singapore, and is also threatening the United States and other areas. Id. In just a few months, SARS has already infected about 2600 persons and killed ninety-five people around the globe. Id. The epidemic is also threatening the global economic recovery. See Geoff Hiscoc, Virus Raises Asian Recession Fear, at http://www.cnn.com/2003/BUSINESS/ asia/ 04/01/asia.sarsimpact.biz/index.html (last visited Apr. 8, 2003) (noting economists' fears that SARS is "potentially the most serious event facing the region since the 1997-98 financial crisis"). On a positive note, it appears as if the international community learned a valuable lesson from its initially slow response to the AIDS pandemic. In the face of impending disruptions of global society and commerce by SARS, the international community is mobilizing a quicker response and chastising China's lackadaisical reaction to the epidemic and her failure to quickly warn her neighbors. The lesson is becoming clearer: a viral outbreak in one country is not an internal matter, a local secret, to be shrouded by the outmoded cloak of national sovereignty, and to be screened from external problem solver and/or decision makers by the myopic prism of national interest. In the age of globalization, marauding microbes threaten the peace, progress, and well-being of global society just as much as two-bit tyrants or terrorists with weapons of mass destruction. The SARS epidemic further highlights the need to continue to rethink the security, sovereignty, intervention, and national interests in the new age of galloping globalization and jet setting microbes. 